\title{
Experimental Modelling of Spinal Anaesthesia in Rats
}

\author{
$\mathrm{PhD}$ Thesis
}

\section{Ildikó Dobos}

Supervisor:

Gyöngyi Horváth MD, DSc

Department of Physiology

Faculty of Medicine, University of Szeged 


\section{The thesis is based on the following articles:}

I. Dobos I, Toth K, Kekesi G, Joo G, Csullog E, Klimscha W, Benedek G, Horvath G, The significance of intrathecal catheter location in rats. Anesth. Analg. 96: 487-492, 2003. Impact factor: 2.210

II. Klimscha W, Horvath G, Szikszay M, Dobos I, Benedek G, Antinociceptive effect of the $\mathrm{S}(+)$-enantiomer of ketamine on carrageenan hyperalgesia after intrathecal administration in rats. Anesth. Analg. 56: 561-565, 1998.

Impact factor: 2.776

\section{Other articles:}

1. Horvath G, Dobos I, Liszli P, Klimscha W, Szikszay M, Benedek G. Antinociceptive effects of the hydrophilic $\alpha 2$-adrenoceptor agonist ST-91 in different test circumstances after intrathecal administration to Wistar rats. Pharmacol. Res. 35: 561-568, 1997.

Impact factor: 0.470

2. Horvath G, Kekesi G, Dobos I, Szikszay M, Klimscha W, Benedek G. Effect of intrathecal agmatine on inflammation-induced thermal hyperalgesia in rats. Eur. J. Pharmacol. 368: 197-204, 1999.

Impact factor: 2.047

3. Joo G, Horvath G, Klimscha W, Kekesi G, Dobos I, Szikszay M, Benedek G. The effects of ketamine and its enantiomers on the morphine- or dexmedetomidine-induced antinociception after intrathecal administration in rats. Anesthesiology 93: 231-241, 2000.

Impact factor: 3.439

4. Csullog E, Joo G, Toth G, Dobos I, Benedek G, Horvath G. Antinociceptive effect of continuous intrathecal administration of endomorphin-1. Pain 94: 31-38. 2001.

Impact factor: 4.541

5. Horvath G, Joo G, Dobos I, Klimscha W, Toth G, Benedek G. Synergistic antinociceptive interactions of endomorphin-1 with dexmedetomidine and/or $\mathrm{S}(+)$-ketamine in rats. Anesth. Analg. 93: 1018-1024. 2001.

Impact factor: 2.279

6. Kekesi G, Joo G, Csullog E, Dobos I, Klimscha W, Toth K, Benedek G, Horvath G. The antinociceptive effect of intrathecal kynurenic acid and its interaction with endomorphin-1 in rats. Eur. J. Pharmacol. 445: 93-96. 2002

Impact factor: 2.342

7. Horvath G, Agil A, Joo G, Dobos I, Benedek G, Baeyens J.M. Evaluation of endomorphin-1 on the activity of $\mathrm{Na}^{+}, \mathrm{K}^{+}$-ATPase using in vitro and in vivo studies. Eur. J. Pharmacol. 458: 291-297, 2003.

Impact factor: 2.352 
8. Kekesi G, Dobos I, Benedek G, Horvath G. Antinociceptive activity of Sempervivum tectorum L. extract in rats. Phytother. Res. 17: 1032-1036, 2003.

Impact factor: 0.803

9. Kekesei G, Dobos I, Benedek G, Horvath G. The antinociceptive potencies and interactions of endogenous ligands during continous intrathecal administration: adenosine, agmatine, and endomorphin-1. Anesth. Analg. 98: 420-426, 2004.

Impact factor: 2.180

10. Horvath G, Kekesi G, Dobos I, Klimscha W, Benedek G, Long-term changes in the antinociceptive potency of morphine or dexmedetomidine after a single treatment. Anesth. Analg. 101: 812-818, 2005.

Impact factor: 2.452

11. Santha P, Oszlacs O, Dux M, Dobos I, Jancso G, Inhibition of glucosylceramide synthase reversibly decreases the capsaicin-induced activation and TRPV1 expression of cultured dorsal root ganglion neurons. Pain, 150: 103-112, 2010.

Impact factor: 5.371

\section{Abstracts}

1. Horvath G. Szikszay M, Dobos I, Benedek G. Intrathecally applied $\alpha 2$-adrenoceptor agonist (hydrophil ST-91) effects on motor functions in rats. Second Congress of the Hungarian Neuroscience Society, Szeged, 26-28 January 1995.

Neurobiology 3; 69, 1995.

2. Klimscha W, Horvath G, Szikszay M, Dobos I, Benedek G, Antinociceptive effects of the S(+) and racemic ketamnine isomers in acute pain tests. MÉT, Szeged, 3-4 July.

Physiology 6: 43, 1996.

3. Horvath G, Dobos I, Szikszay M, Benedek G, Intrathecally coadministered verapamil potentiates the ST-91 induced antinociception in rats. MÉT, Szeged, 3-4 July.

Physiology 6: 41, 1996.

4. Horvath G, Klimscha W, Dobos I, Szikszay M, Benedek, G, Intrathecal agmatine pretreatment decreases the hyperalgesia and potentiates the morphine induced antinociception in rats. $16^{\text {th }}$ Annual ESRA Congress, London, England, 17-20 September, 1997.

Regional Anesthesia 9/3: 67, 1997.

5. Klimscha W, Horváth G, Dobos I, Szikszay M, Benedek G, Intrathecalisan adott ketamin enantiomerek fájdalomcsillapitó hatásának analizálása gyulladásos fájdalomteszten patkányon. MÉT LXII. Vándorgyülése, Pécs, Július 9-12. 1997.

6. Dobos I, Horvath G, Szikszay M, Benedek G, Evaluation of chronic intrathecal catheterization in rats. Magyar Idegtudományi Társaság 5. Konferenciája, Debrecen, Január 21-24. 1998.

Neurobiology 6: 469-470, 1998.

7. Horvath G, Szikszay M, KlimschaW, Dobos I, Kekesi G, Benedek G, Eisenach,J. Effect of intrathecal agmatine on morphine-induced spinal analgesia in rats. Annual Congress of European Society of Anaesthesiologists, Barcelona, Spain, 25-28 April, 1998.

Br. J. Anaest. 80:167, 1998. 
8. Horváth G, Klimscha W, Dobos I, Szikszay M, Kékesi G, Benedek G, Intrathecalisan adott agmatine (endogén alfa2-adrenoceptor- és imidazoline receptor agonista) antinociceptív hatása gyulladásos fájdalomteszten patkányon. MÉT LXII. Vándorgyülése, Debrecen, Július 8-11, 1998.

9. Horvath G, Joo G, Klimscha W, Dobos I, Szikszay M, Benedek G, The interaction of $\mathrm{S}(+)$ ketamine with dexmedetomidine after intrathecal administration in rats. European Socyety of Anaesthesiologists, 8th Annual Meeting with the Austrian International Congress, Vienna, Austria, 1-4 April, 2000.

Eur. J. Anaesth. 17 (Suppl 19): 176-177, 2000.

10. Horvath G, Joo G, Baeyens J.M, Szikszay M, Dobos I, Benedek G, Interaction of the Na+-K+ pump inhibitor ouabain with $\mu$-opioid receptor agonists after different routes of administration. The Physiological society Proceedings of the Scientific meeting held at Hungarian Academic of Sciences, Budapest, 27-29 May, 2000.

J. Physiol. 526 (P): 174P-175P, 2000.

11. Horvath G, Joo G, Klimscha W, Dobos I, Csullog E, Szikszay M, Benedek G. The interaction of $\mathrm{S}(+)$ ketamine with endomorphin-1 after intrathecal administration in rats. Pain in Europe III, Nice, France, 26-29 September, 2000.

12. Joo G, Horvath G, Dobos I, Bayens J.M, Szikszay M, Benedek G, Az új endogén $\mu$-opioid agonista, endomorphin-1 fájdalomcsillapító hatásának befolyásolása különbözö szerkekel. A Magyarországi Fájdalom Társaság 2000. évi Tudományos Ülése. Siófok, Október 13-14.

Fájdalom-Pain 1: 29-30, 2000.

13. Horvath G, Joo G, Dobos I, Klimscha W, Tóth G, Kekesi G, Benedek G, Endomorphin-1 és dexmedetomidin szinergisztikus antinociceptiv interakciója intrathecalis beadás után patkányban. Magyar Idegtudományi Társaság VIII. Kongresszusa, Szeged, Január 24-27, 2001.

Neurobiology 9: 199-200, 2001.

14. Csullog E, Horvath G, Joo G, Dobos I, Kekesi G, Benedek G, Ntinociceptive effect of continous intrathecal infusion of endomorphin-1 in rats. Euopean Society of Anaesthesiologists, 9th Annual Meeting with the Swedish Society of Anaesthesiology, Gotenburg, Sweden, 7-10 April, 2001.

Eur. J. Anaesthesiol. 18(S21): 139, 2001.

15. Horváth G, Joó G, Kékesi G, Csüllög E, Dobos I, Benedek G, Intrathecalis endomorphin-1 infúzió antinociceptív hatása patkányban. Fiatal Aneszteziológusok V. Kongresszusa, Sopron, Május 10-12, 2001

Aneszteziol. Int. Ther. 31 (Suppl. 1): 39, 2001.

16. Horvath G, Joo G, Dobos I, Klimscha W, Kekesi G, Benedek G, The interaction of endomorphin1 with dexmedetomidine at spinal level in rats. 11th European Congress of Anaesthesiology, Florence, Italy, 5-9 June, 2001.

Minerva Anesthesiol. 67 (S1): 137-138, 2001.

17. Joó G, Kékesi G, Csüllög E, Dobos I, Benedek G, Horváth G, Intrathecalis adenozin infúzió antinociceptív hatása patkányban. Magyar Élettani Társaság LXVI. Vándorgülése, Szeged, Június $6-8,2001$.

18. Kékesi G, Joó G, Csüllög E, Dobos I, Benedek G, Horváth G, Intrathecalis kinurénsav infúzió antinociceptív hatása patkányban. Magyar Élettani Társaság LXVI. Vándorgülése, Szeged, Június 6-8, 2001. 
19. Kekesi G, Horvath G, Joo G, Dobos I, Csülög E, Klimscha W, Benedek G, The antinociceptive effect of intrathecal kynurenic acid and its interaction with endomorphin-1 in rats. Austrian International Congress and Rudolf Kucher Forum, 1st International Danube Symposium Anaesthesia \& Intensive Care: The Emerging Discipline, Vienna, Austria, 12-14 September, 2001. Br. J. Anaesth. 87 (S1): 43, 2001.

20. Horváath G, Kékesi G, Csüllög E, Joó G, Dobos I, Benedek G, Két endogén ligand interakciója a fájdalomcsillapításban gerincvelői szinten. A Magyar Fájdalom Társaság Tudományos Ülése, Siófok, Október 19-20, 2001.

Fájdalom/Pain 2: 27, 2001.

21. Horvath G, Kekesi G, Joo G, Dobos I, Benedek G, The antinociceptive potencies and interaction of endogenous ligands at spinal level. IBRO Intarnationa Workshop on Signalling Mechanisms in the Central and Peripheral Nervous System, Debrecen, 24-26 January, 2002.

Neurobiology 9: 318-319, 2002.

22. Horváath G, Csüllög E, Kékesi G, Dobos I, Benedek G, Különböző endogén ligandok potenciális szerepe a fájdalomcsillapításban. Magyar Aneszteziológiai és Reanimációs Társaság 3. Kongresszusa, Siófok, Május 29-30, 2002.

Aneszteziol. Int. Ther. 32 (Suppl 2): 17, 2002.

23. Csüllög E, Kékesi G, Dobos I, Horváth G, Benedek G, Sempervivum tectorum kivonatának antinociceptív hatása patkányban. Magyar Aneszteziológiai és Reanimációs Társaság 31. Kongresszusa, Siófok, Május 29-30, 2002.

Aneszteziol. Int. Ther. 32 (Suppl 2): 43, 2002

24. Kekesi G, Joo G, Csullog E, Dobos I, Benedek G, Horvath G, Calibration of intrathecal catheter tip position in rats. $1^{\text {st }}$ World Congress on Regional Anaesthesia and Pain Therapy, Barcelona, Spain, 29 May-1 June, 2002.

Int. Monitor 14: 80, 2002.

25. Horvath G, Kekesi G, Csullog E, Dobos I, Klimscha W, Bemedek G, The inflammatory pain relief by different endogenous ligands in rats. $4^{\text {th }}$ International Congress of Pathophysiology, Budapest, 29 June-5 July, 2002.

Acta Physiol. Hung. 89: 318, 2002.

26. Kekesi G, Dobos I, Benedek G, Horvath G, The antinociceptive potency of sampervivum tectorum extract. $4^{\text {th }}$ International Congress of Pathophysiology, Budapest, 29 June-5 July, 2002. Acta Physiol. Hung. 89: 178, 2002.

27. Kekesi G, Dobos I, Benedek G, Horvath G, The antinociceptiv interaction of two endogenous ligands: endomorphin-1 and agmatine. Magyar Idegtudományi Társaság IX. Konferenciája, Balatonfüred, Január 22-25, 2003.

Clin. Neurosci./Ideggyógy. Szle. 56 (Suppl): 45, 2003.

28. Kekesi G, Dobos I, Benedek G, Horvath G, Adenosine in spinal antinociception. $3^{\text {rd }}$ FEPS Congress, Nice, France, 28 June -2 July, 2003.

29. Horvath G, Kekesi G, Dobos I, Benedek G, Long-lasting changes in the antinociceptive potency of morphine or dexmedetomidine after repeated treatments. $6^{\text {th }}$ IBRO World Congress of Neuroscience, Prague, Czeh Republic, 10-15 July, 2003. 
30. Kekesi G, Joo G, Dobos I, Benedek G, Horvath G, Long-term effects of single morphine or dexmedetomidine administration on different pain tests. IBRO International Workshop on Neuronal Circuits: from Elementary to complex Functions, Budapest, 29-31 January, 2004. Clin. Neurosci./Ideggyógy. Szle. 57 (Suppl. 1): 29, 2004

31. Horvath G, Kekesi G, Szikszay M, Dobos I, Klimscha W, Benedek G, Morphine induces a delayed type of acute tolerance in acute but not in inflammatory pain model. $5^{\text {th }}$ Meeting of the European Opioid Conference, Visegrád, 4-7 April, 2004.

32. Santha P, Oszlacs O, Dobos I, Jancso G, Depletion of the lipid raft component GM1 ganglioside impairs NGF mediated regulatio of the capsaicin sensitivity of nociceptive primary sensory neurons. IBRO International Workshop on Complex Neural Networks „From synaptic transmission to seeing the brain in action" Debrecen, 24-26 January, 2008. Ideggyógy. Szle./Clin. Neurosci. 61 (S1): 55, 2008.

33. Jancso G, Oszlacs O, Dobos I, Santha P, Glucosylceramide synthase regulatest the capsicin sensitivity of cultured dorsal root ganglion neurons. $6^{\text {th }}$ Forum of European Neuroscience Societies. Geneva, Switzerland, 12-16 July, 2008.

34. Jancsó G, Oszlács O, Dobos I, Dux M, Sántha P, Ganglioside modulation of capsaicin/transient receptor potential vanilloid type 1 receptor (TRPV1) function and expression. Joint Meeting of the European Neuropeptide Club and the Summer Neuropeptide Conference, Salzburg, Austria, 20-23 July, 2009.

Neuropeptides: 43: 427, 2009.

35. Jancso G, Oszlács O, Dobos I, Dux M, Santha P, NGF-regulated expression of TRPV1 is mediated by gangliosides in cultured rat dorsal root ganglion neurons. $7^{\text {th }}$ FENS Forum of European Neuroscience, Amsterdam, Netherlands, 3-7 July, 2010.

36. Santha P, Dobos I, Oszlacs O, Jancso G, Chemical sensitivity of rat primary sensory neurons is regulated by glusocylceramide synthase. $8^{\text {th }}$ Congress of the European Pain federation EFIC, Florance, Italy, 9-12 October, 2013. 


\section{CONTENTS}

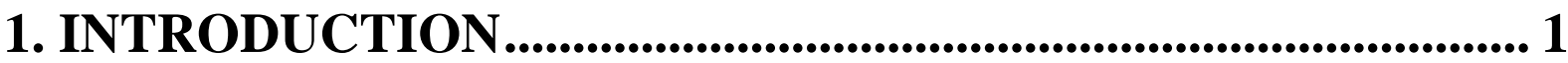

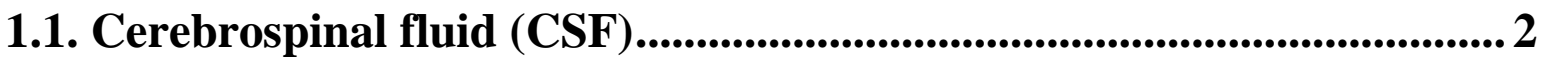

1.2. Pain transmission .......................................................................................... 3

1.2.1. Dorsal root ganglia...................................................................................... 3

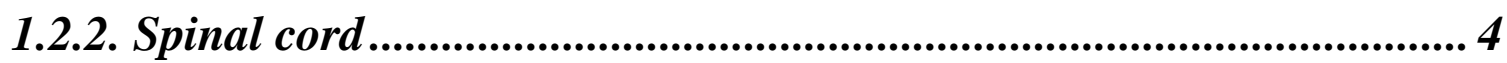

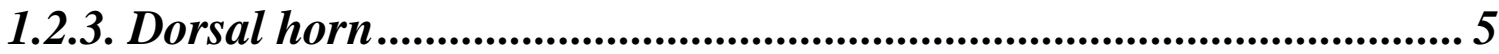

1.2.4. Ascending nociceptive pathways.............................................................. 8

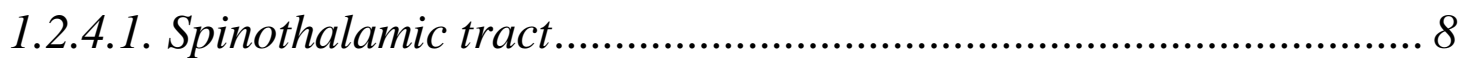

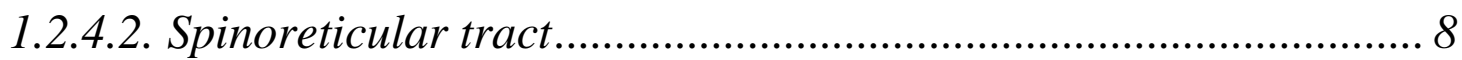

1.2.4.3. Spinomesencephalic tract ............................................................ 9

1.3. Role of glutamate receptors in nociception at spinal level................... 10

1.3.1. Glutamate receptors ................................................................................... 10

1.3.2. NMDA receptor .......................................................................................... 11

1.3.3. NMDA receptor modulation ................................................................ 13

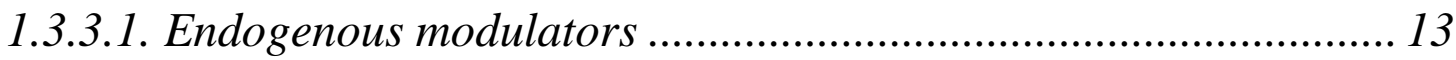

1.3.3.2. Exogenous modulators............................................................... 18

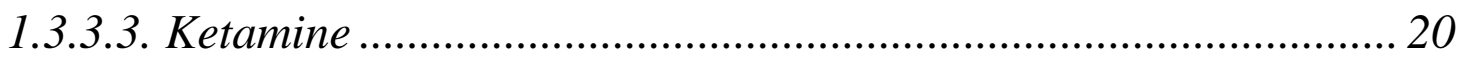

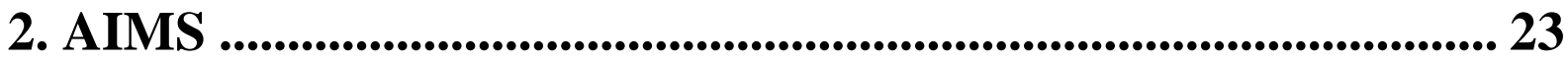

3. MATERIALS AND METHODS ........................................... 25

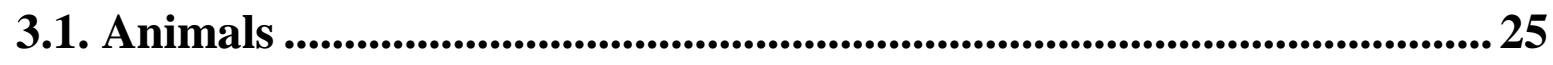

3.2. Intrathecal catheterization...............................................................25 
3.3. Drugs ................................................................................................................................. 25

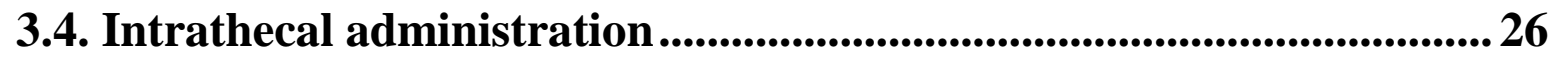

3.5. Carrageenan-induced inflammation..................................................26

3.6. Pain tests ......................................................................................................................... 26

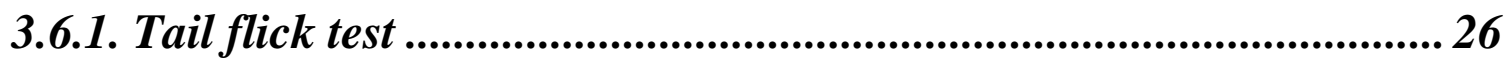

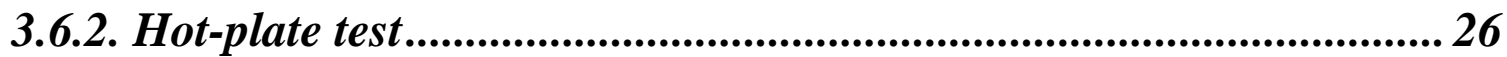

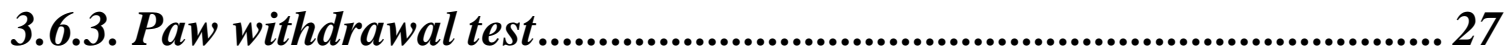

3.7. Assessment of motor impairment..............................................................227

3.7.1 Determination of motor paralysis ............................................................. 27

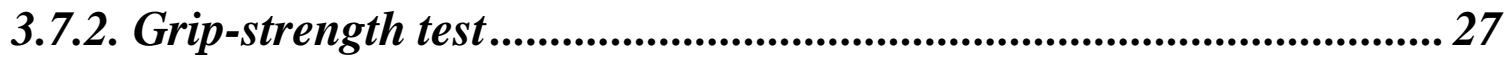

3.8. Localization of the catheter tip................................................................28

3.9. Experimental protocols ............................................................................... 28

3.10. Data analysis......................................................................................................... 29

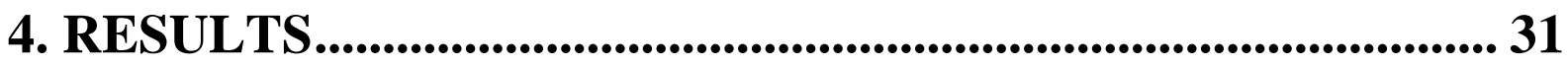

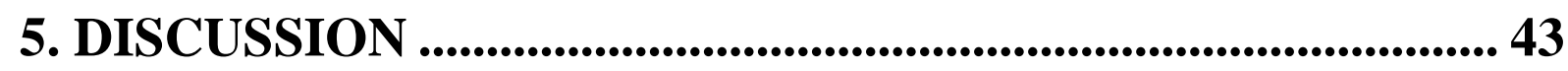

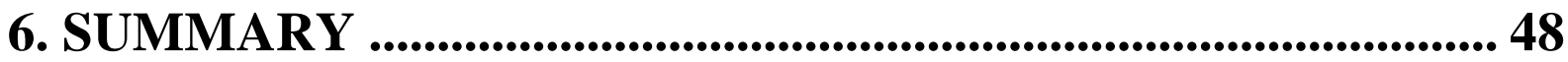

AKNOWLEDGEMENTS ............................................................50

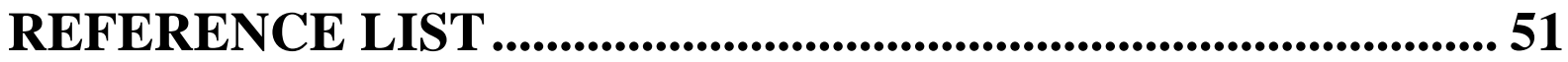




\section{Abbreviations}

AMPA - $\alpha$-amino-3-hydroxyl-5-methyl-4-isoxazole-propionate

CDI - calcium-dependent inactivation

CGRP - calcitonin gene-related-peptide

$\mathrm{CSF}$ - cerebrospinal fluid

DH-dorsal horn

DRG - dorsal root ganglia

EPSP - excitatory postsynaptic potential

FRAP - fluoride-resistant acid phosphatase

GDNF-glial cell line-derived neurotophic factor

HP - hot plate

5-HT - 5-hidroxytriptamine

mGluR - metabotropic glutamate receptor

$\%$ MPE - maximal possible effect \%

NGF - nerve growth factor

$\mathrm{NO}$ - nitric oxide

NMDA - N-methyl-D-aspartate

NT-3 - neurotrophin-3

NR1 - NMDA receptor subunit 1

NR2 - NMDA receptor subunit 2

$\mathrm{NS}$ - nociceptive specific

PAG - periaqueductal grey

$\mathrm{PCP}-$ phencyclidine

PWD - paw withdrawal

$\mathrm{SP}$ - substance P

$\mathrm{TF}$ - tail flick

TRPV1R - transient receptor potential vanilloid 1 receptor

VPL - ventral posterior lateral nucleus

VPM - ventral posterior medial nucleus

WDR - wide-dynamic range 


\section{INTRODUCTION}

One of the main purposes of medicine is to relieve pain. Several examinations have been made to reveal the processes induced by painful stimuli. Different animal models are used to characterise physiological and behavioural changes after noxious stimuli $(14,75,84,91,102)$.

The sensation of pain is fundamental in the maintenance of the biological integrity of the body, but chronic pain status cause severe somatic and psychic impairment, which give rise to considerable social and economic burden not only on the individual but also on the society.

The International Association for the Study of Pain (IASP) defines pain as 'an unpleasant sensory and emotional experience associated with actual or potential tissue damage, or described in terms of such damage' (6). This definition takes into consideration the subjectivity of the painful phenomenon and permits the understanding of important concepts concerning this subject. A noxious stimulus is capable of provoking a real or potential injury, not necessarily causing pain. In this context, pain experienced by virtue of this type of stimulus is characterized as nociceptive pain. There is a difference between the terms nociception and pain. Nociception refers to the neurophysiologic manifestations generated by noxious stimulus, while the pain requires the capacity of abstraction and the elaboration of sensory impulses $(2)$.

Pain represents a complex sensory modality accompanied by affective, motivational and cognitive aspects, and associated with neurovegetative responses (2). In most cases, pain is initiated by events that occur on the skin, ligaments and articular capsules, or in deep tissues such as connective tissues of visceral organs, periosteum, tendon, or muscles. Specialized primary afferent neurons, called nociceptors, respond to noxious stimuli that can produce tissue damage. There are two major classes of nociceptors:

Unimodal nociceptors (A $\delta$ afferent) are thermosensitive or mechanosensitive, and respond to sharp mechanical pressure or tissue temperatures of $45^{\circ} \mathrm{C}$ or more respectively.

Polymodal nociceptors (C fibers) react to mechanical, thermal or chemical stimulation $(6,12,27)$. Both types of nociceptors are primary sensory neurons, whose cell bodies are located in dorsal root ganglia (DRG) or in a cranial nerve ganglion (V, VII, IX, X). 
The first-order neurons transmitting pain impulses have two types. There are (1) smalldiameter myelinated fibres of the A $\delta$ group that are responsible for 'fast' or 'first' pain and (2) non-myelinated $\mathrm{C}$ fibres (dorsal root $\mathrm{C}$ fibres) that give rise to a 'slow' or 'second' duller, more diffuse type of pain. Both types of first-order pain fibres terminate in the superficial layers of the dorsal horn (DH) of the spinal cord or in cervical nerve of trigeminal nucleus $(6,12,27)$. The further processing of nociceptive information in different central structure may lead to pain sensation and adequate behavioural responses.

\subsection{Cerebrospinal fluid (CSF)}

The best way to examine the action of a drug at the spinal level in an awake animal is to introduce the drug into the spinal subarachnoid fluid and thereby bathe the spinal cord in the pharmacologically active solution.

In the region of the medulla oblongata, the central canal of the spinal cord enlarges to form the fourth ventricle. The ventricles are lined with a ciliated columnar ependyma. In the roof of the third and fourth ventricles and the medial wall of the lateral ventricle, the ependyma covering the capillary loops of the plexus choroideus becomes cuboidal (31). They secrete the cerebrospinal fluid (CSF). CSF is located within the ventricles, spinal canal, and subarachnoid spaces. CSF flows from the lateral ventricles through the interventricular foramina of Monro into the third ventricle. From there it flows into the fourth ventricle through the cerebral aqueduct of Sylvius and then through the foramina of Magendie and Luschka into the subarachnoid space. The subarachnoid space lies between the arachnoid and the pia mater, which, together with the dura mater, form the three meningeal layers that cover the brain. The CSF circulates through the freely communicating subarachnoid cisterns at the base of the brain. From the cisterns, most of the CSF is directed upward over the cerebral hemispheres and smaller amounts pass downward spinal canal and around the spinal cord. CSF is reabsorbed over the convexity of the brain into the venous sinuses (46). The volume of CSF varies between 10-20\% of brain weight, it is estimated to be approximately 140-150 $\mathrm{ml}$ in humans and it ranges from 300 to $400 \mu \mathrm{l}$ in adult rats $(7,19,72)$. The lateral and third ventricles contain approximately $12 \mathrm{ml}$, and the spinal subarachnoid space about $30 \mathrm{ml}$ with a production rate of $21 \mathrm{ml} / \mathrm{hr}$ in human. The subarachnoid space and major cisterns of the brain 
contain most of the CSF. The turnover rate of total CSF is species dependent and varies between approximately $1 \mathrm{hr}$ for rat and $5 \mathrm{hr}$ for human $(18,46)$.

The spinal cord and the roots of the spinal nerves are closely surrounded by dura mater, a glassy, tough membrane. Only in the lumbar region is it pushed off the surface of the spinal cord by the dorsal and ventral roots. Usually the roots penetrate the tube of dura mater through several closely fitting openings and each is accompanied by a dural sheath, which is attached to the spinal ganglion as well as to the periosteum of the intervertebral foramen. Sparse narrow blood vessels traverse the epidural space. Especially in the dorsal part of the thoracic and sacral region, it contains a $0.3-0.5 \mathrm{~mm}$ layer of fat. In the cervical and lumbar region it is less than $0.3 \mathrm{~mm}$ thick. The arachnoid, a clear membrane, is loosely but not displaceable connected with the thin pia mater.

\subsection{Pain transmission}

\subsubsection{Dorsal root ganglia}

The DRG and some cranial nerves (V, VII, IX, X) ganglion contain most of the cell bodies of many of the sensory neurons that project to the spinal cord and to the periphery via the dorsal roots. The trigeminal ganglion (TRG) is a sensory ganglion of the face whereas the DRG associate with the rest of the body.

The cell bodies of primary afferents in the DRG or TRG can be divided into various subpopulations based on their neurochemistry, anatomy and physiology. First, large- and medium-sized cells $(60-120 \mu \mathrm{m})$ have high levels of neurofilament and giving rise to large myelinated $(\mathrm{A} \alpha / \beta)$ fibres and receive input from peripheral mechanoreceptors (62). The second major group of DRG cells are small cells $(14-30 \mu \mathrm{m})$, which have mainly unmyelinated (C) axons and are predominantly nociceptors, comprise two main populations: one part of the cells, which is referred to as CGRP/IB4- cells, because they constitutively synthesize the neuropeptide (calcitonin gene-related-peptide (CGRP) and substance P (SP), do not bind isolectin B4 Griffonia simplicifolia (IB4). These cells express transient receptor potential vanilloid 1 (TRPV1) and neurotrophic tyrosine kinase receptor type A receptors thus this population responds to the nerve growth factor (NGF) (22). The other part of the cells bind IB4 and express a non-lysosomal fluoride-resistant acid phosphatase (FRAP). This 
group, which is referred to as IB4+, do not contain neuropeptides or only in low levels. The population of IB4+ cells express TRPV1 receptors also and selectively express P2X3 ATPgated cation channels. In contrast to the CGRP/IB4- cells, the IB4+ population of nociceptors do not normally respond to NGF but they respond to glial cells line-derived neurotrophic factor (GDNF). These cells express GDNF family receptor $\alpha-1$ (GFR $\alpha 1)$, GFR $\alpha 2$ and/or GFR $\alpha 3$ receptors (62). The central terminals of the two groups project to distinct regions of the dorsal spinal cord. IB4+ C-fibres project principally to inner lamina II (substantia gelatinosa) whereas the IB4- peptide rich C-fibres terminate more superficially in lamina I and outer lamina II (22) .

An intermediate group between these two major populations comprises CGRP containing cell that are medium sized with finely myelinated $\mathrm{A} \delta$ axons and terminate in lamina I and $\mathrm{V}$ of the spinal cord. Most of these cells are nociceptors of the high threshold mechanoreceptor type (62). This population of cells express TRPV2 receptors and respond to NGF and neurotrophin-3 (NT-3) (62). A small part of intermediate group cells provide mechanothermal receptors for high temperatures $\left(45-50{ }^{\circ} \mathrm{C}\right)$ and some receptors for intense cold $\left(-15^{\circ} \mathrm{C}\right)$ and sensitized to vigorous mechanical stimuli at nonnoxious thresholds (2) .

As the primary nociceptive neurons enter the spinal cord run up and down for one or two spinal cord segments, before they penetrate into the grey matter of the DH. The tract that ascends/descends before synapsing is known as Lissauer's tract (77). Generally speaking C fibres appear to travel in the most lateral part of the dorsal white matter, including Lissauer's tract, and A fibres most medially. Lissauer's tract is the bundle of fine fibres situated just lateral to the entering dorsal rootlets with a poorly defined border towards the dorsolateral funiculus. More than two thirds of axons, in the rat Lissauer's tract at thoracic, and lumbosacral levels are primary afferents, and majority are unmyelinated $(67,96)$.

\subsubsection{Spinal cord}

The spinal cord is the most caudal part of the central nervous system (CNS) and in many respects, the simplest part.

The weight of the rat spinal cord increases with the changing of the body weight as follows: $100 \mathrm{~g}$ of animal has near $0.43 \mathrm{~g}, 200 \mathrm{~g}$ of body weight it is $0.58 \mathrm{~g}$ and it approaches $0.7 \mathrm{~g}$ in animal of $300 \mathrm{~g}$ body weight (31). In females, spinal cord weight averages $2 \%$ higher than it 
does in males. The length in adult male rats varies from 113 to $125 \mathrm{~mm}$. It extends from the base of the skull to the fourth lumbar vertebra. It is divided into four major regions: cervical, thoracic, lumbar and sacral (31) .

The first thoracic segment ends at the last cervical vertebra; the first lumbar segment begins at the caudal end of the $10^{\text {th }}$ thoracic vertebra, and from there on the coccygeal part runs to the cranial third of the $4^{\text {th }}$ lumbar vertebra.

The cord is divided into grey matter and surrounding white matter. The grey matter, which contains nerve cell bodies, is shaped like letter $\mathrm{H}$, with each side subdivided into dorsal (or posterior) and ventral (or anterior) horns.

The DH is larger where sensory nerves from the limbs enter the cord because the limbs have a greater density of sensory receptors and thus send more fibres to the cord. These regions of the cord are known as lumbosacral and cervical enlargements.

The ventral horn contains interneurons in addition to motor neurons, whose axons exit the spinal cord and innervate skeletal muscles.

In the thoracic and upper lumbar regions of the spinal cord, the lateral horn interposes between the dorsal and ventral horns. The lateral horn contains preganglionic visceral motor neurons of the sympathetic nervous system. These neurons send their axons to synapse on sympathetic ganglia that innervate autonomic organs (45).

Various types of interneurons in the grey matter modulate information flowing from the sensory neurons toward the brain or/and the motor neurons, as well as information passed between groups of motor neurons.

The white matter surrounding the grey matter is divided into dorsal, lateral, and ventral columns. The dorsal columns, which lie between the two DHs of the grey matter, contain ascending axons that carry somatosensory information to the brainstem. The lateral columns include both ascending axons and fibres descending from the brainstem and neocortex that innervate interneurons and motor neurons in the spinal cord. The ventral columns also include ascending and descending axons (46) .

\subsubsection{Dorsal horn}

The DH contains four different neuronal components (94):

1. central terminals of primary afferents 
2. projecting neurons with long ascending axons synapting to the brain

3. interneuron (intrinsic spinal neurons)

4. descending axons from various parts of the brain

The primary sensory afferent fibres terminate predominantly in the DH of the spinal cord. The DH can subdivide into six distinct layers based on the cytological features (11). Classes of primary afferent neurons that convey distinct modalities terminate in distinct laminate of the DH. Thus, there is a close correspondence between the functional and anatomical organization of neurons in the DH of the spinal cord (46).

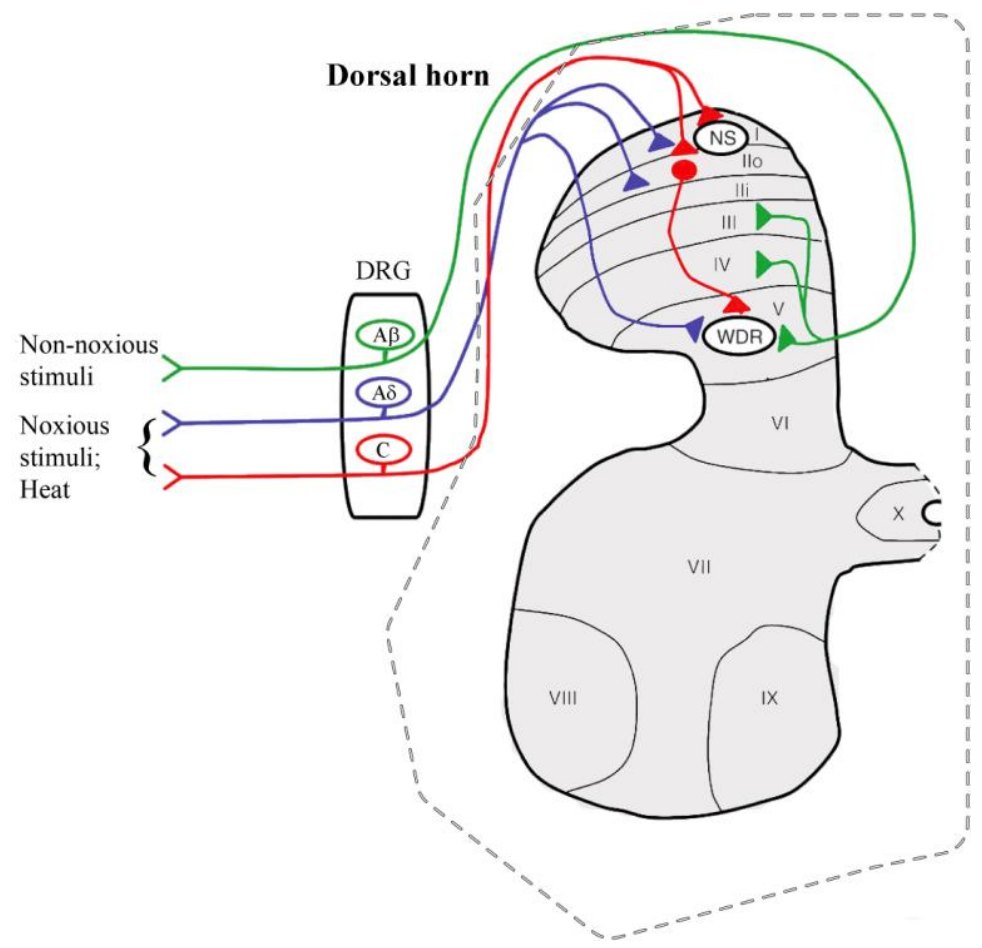

Fig.1 Schematic representation of dorsal horn (source:http://www.fastbleep.com/biology-notes/39/142/888)

Lamina I receives particular attention in relation to nociception because it is a specialised region for the termination of nociceptive afferents and contains nociceptive specific (NS) cells with respond only to noxious stimuli and project to higher brain centres (Fig. 1) (96). The majority of these neurons receive direct synaptic input from $\mathrm{A} \delta$ and $\mathrm{C}$ polymodal fibres (CGRP/IB4- small diameter cells) $(27,46)$. The other group of cells in this lamina are the wide dynamic range (WDR) neurons what respond to mechanical, thermal and chemical stimuli coming from the $\mathrm{A} \delta, \mathrm{C}$ and $\mathrm{A} \beta$ fibres. Because of convergence of noxious and nonnoxious fibres, this group plays a fundamental role in the mechanisms of segmental 
suppression of pain involved in the gate control theory $(2,66)$. They are found in deeper laminae (IV, V, VI, X) too (2).

Lamina II (subtantia gelatinosa) has been subdivided based on physiological and anatomical data, into inner and outer regions (IIi and IIo). The ventral region (IIi) contains synaptic contacts of cells that responding only to light brush and additionally the small-diameter IB4+ non peptide-expressing nociceptive cells afferent axons enter here. While the more dorsal part (IIo) has the largest number of cells afferentation that responding to light and heavy mechanical stimuli and to noxious heat and chemicals (small-diameter CGRP/IB4- cells) $(46,96)$.

Lamina III is located ventral to the substantia gelatinosa and contains neurons that receive monosynaptic input from $A \beta$ fibres. These neurons, respond predominantly to non-noxious stimuli, have quite restricted receptive fields that are organized topographically (46) .

Lamina IV contains large cells with dorsally rising dendrites and small stellate cells. They excite only by light mechanical stimuli to the skin and the response of these cells does not increase if the intensity of the pressure stimulus is increased (96).

Lamina $\mathrm{V}$ contains primarily wide-dynamic-range (WDR) neurons that project to the brainstem and to regions of the thalamus and respond to a variety of inputs from low to high threshold mechanical, thermal and chemical stimuli by way of the full range of diameters of afferent fibres (96). These neurons receive monosynaptic input from $A \beta$ and $A \delta$ fibres. They also receive input from $\mathrm{C}$ fibres, either directly on their dendrites, which extend dorsally into the superficial DH, or indirectly via excitatory interneurons. Many neurons in lamina V also receive nociceptive input from visceral structures (46).

Neurons in lamina VI make up the ventral boundary of the DH (96). They receive inputs from large-diameter $(\mathrm{A} \alpha)$ afferents from muscles and joints and respond to non-noxious manipulation of joints (46). However, they also respond to low and high-threshold cutaneous afferents. This convergent input from both specialized muscle receptors, cutaneous and visceral inputs is under selective modality control by way of descending pathway from the CNS (96).

Neurons in ventral horn laminae VII and VIII, many of which respond to noxious stimuli, have more complex response properties because the nociceptive inputs to lamina VII neurons are polysynaptic. Furthermore, although most DH neurons receive input from only one side of the body, many neurons in lamina VII respond to stimulation of either side. Thus, neurons of 
lamina VII, through their connections with the brainstem reticular formation, may contribute to the diffuse nature of many pain conditions $(46,96)$.

A specialized group of cells gathered around the central canal make up lamina X. They may be related to pain mechanisms too, since some respond to high intensity bilateral stimuli and contain the same array of peptides (CGRP, SP) which characterize laminae I and II, and it could be one of the polysynaptic chains linking the entire length of cord and brainstem (96) .

\subsubsection{Ascending nociceptive pathways}

As in other sensory systems in the mammals, the somatosensory system includes a number of parallel ascending pathways. Nociceptive information is transmitted from the spinal cord to the brain over several different ways, including the spinothalamic, spinoreticular, spinomesenchephalic, spinocervical and second-order dorsal column tracts (12). The functions of the ascending nociceptive systems include signalling of the sensory discriminative aspects of pain, and they trigger motor and autonomic adjustments, as well as activating antinociceptive systems $(12,31)$.

\subsubsection{Spinothalamic tract}

The spinothalamic tract is the most prominent ascending nociceptive pathway in the spinal cord $(12,31)$. It comprises the axons of nociceptive and wide-dynamic-range neurons in laminate I and V-VII of the DH. The axons decussate within the spinal cord and they ascend within the anterolateral white matter $(46,78,96)$. The nociceptive information from the body terminates in the ventral posterior lateral (VPL) nucleus and from the face - through the trigeminothalamic tract - terminates in the ventral posterior medial (VPM) nucleus (A $\delta$ fibres) and intralaminar nuclei ( $\mathrm{C}$ fibres) of the thalamus (78). These nuclei send their axons to primary and secondary somatosensory cortex. The nociceptive information transmitted to these cortical areas is thought to be responsible for the discriminative component of pain: identifying the location, the intensity and quality of the stimuli (78).

\subsubsection{Spinoreticular tract}

The spinoreticular tract comprises the axons of neurons in laminae VII and VIII. It ascends in the anterolateral quadrant of the spinal cord and terminates in both the reticular formation (in particular the parabrachial nucleus) and intralaminar nuclei of the thalamus. In contrast to the spinothalamic tract, many of the axons of the spinoreticular tract do not cross the midline 
(46). Neurons in the parabrachial nucleus project to the hypothalamus and the amygdala, thus providing nociceptive information to circuits known to be concerned with motivation and affection. These parabrachial targets are also the source of projections to the periaqueductal grey (PAG) matter of the midbrain, a structure that plays an important role in the descending control of activity in the pain pathway and it is likely to trigger somatic and autonomic motor reflexes $(78,96)$. The intralaminar nuclei of the thalamus provide nociceptive signals to the insula and to the cingulate cortex.

\subsubsection{Spinomesencephalic tract}

The spinomesencephalic tract comprises the axons of neurons in laminate I and V. It projects in the anterolateral quadrant of the spinal cord to the mesencephalic reticular formation and PAG matter via the spinoparabrachial tract and project to the amygdala, a major component of the limbic system which is involved in the emotion $(46,78)$. Thus, the spinomesencephalic tract is thought to contribute to the affective component of pain (46). Because of stimulation in the PAG results in analgesia, this structure plays an important role in the descending control of pain pathway $(2,96)$. Stimulation of the PAG activates enkephalin-releasing neurons that project to the 5-HT (serotonin) releasing raphe nuclei in the brainstem and descends to the $\mathrm{DH}$ of the spinal cord connecting with the "inhibitory interneurons" in

Laminae II. When this pathway activated, these interneurons in the DH release either enkephalin or dynorphin (endogenous opioid neuromodulators), which bind to $\mu$ - and $\kappa$ opioid receptors on the axons of incoming $\mathrm{C}$ and $\mathrm{A} \delta$ fibres. The activation of the $\mu$-opioid receptors inhibit the release of SP from these incoming first-order neurons and, in turn, inhibit the activation of the second-order neuron that is responsible for transmitting the pain signal in the spinothalamic tract to the VPL of the thalamus. Thus, the nociceptive signal can be inhibited before it reaches the cortical areas that interpret the signal as "pain". 


\subsection{Role of glutamate receptors in nociception at spinal level}

Tissue injury triggers the production and liberation of a diverse array of ions, nucleotides, lipids, peptides, amino acid derivatives and proteins at the periphery capable of activating nociceptors or augmenting nociceptor responses to different stimuli. Electrophysiological and pharmacological studies of cultured, dissociated nociceptive neurons have revealed that certain agents (e.g. protons and capsaicin) directly depolarize nociceptive neurons by triggering the opening of cation channels permeable to $\mathrm{Na}^{+}$and/or $\mathrm{Ca}^{2+}$. In contrast, agents such as bradykinin and NGF act on G protein-coupled receptors or TRP, respectively, to trigger intracellular signalling cascades that in turn sensitize depolarizing cation channels to their respective physical or chemical regulators. Still other agents (e.g. glutamate, acetylcholine and adenosine triphosphate) activate both ion channels and $\mathrm{G}$ protein coupled receptors to produce a spectrum of direct and indirect effects on nociceptor membrane potential $(12,61,101)$.

Glutamate is one of the main excitatory neurotransmitters of somatosensory transmission pathways. Glutamate acts on several ionotropic and metabotropic glutamate receptors, which are widely distributed in spinal nociceptive circuits (44). Glutamate also exerts a crucial role in the developing and the mature nervous system, since it regulates neurogenesis, axonal sprouting, synaptogenesis and programmed cell death (apoptosis) (93). The overactivation of glutamate receptors is a major cause of $\mathrm{Ca}^{2+}$ overload in cells, potentially leading to cell damage and death (92) .

Glutamate level is high in the DRG and it is colocalized with neuropeptides like CGRP and SP, in peptidergic primary afferents and there is a high density of glutamatergic binding sites in the DH on interneurons and in descending nociceptive neurons $(20,23)$.

\subsubsection{Glutamate receptors}

Glutamate receptors are divided into the two categories: metabotropic (mGlu) which linked to G-proteins that modulate intracellular second messengers such as inositol phosphates and cyclic nucleotides and ionotropic, which are associated with ion channels.

Metabotropic Glu receptors can be separated into three groups based on their amino acid sequence homology: 
Group I mGlu receptors include mGlu1 and mGlu5 receptor subtypes and their associated alternatively spliced variants. This receptor subclass predominantly couples to Gq/G11 Gproteins to stimulate phospholipase $\mathrm{C}(8,39)$.

Group II subclass consists of mGlu2 and mGlu3 receptors and couples to Gi/Go G-proteins to inhibit adenylyl cyclase $(8,39)$.

Group III subclass is comprised of mGlu4, mGlu6, mGlu7 and mGlu8 receptors and isoforms of mGlu7 and mGlu8. This receptor subclass couples to Gi/Go G-proteins also $(8,39)$.

The ionotropic receptors can be divided into 3 subcategories according to their activation by different agonists:

1. NMDA receptors are activated by N-methyl-D-aspartate

2. AMPA receptors are activated by $\alpha$-amino-hydroxy-5-methyl-4-isoxazole propionic acid

3. kainate receptors are activated by kainic acid.

All of the mammalian ionotropic glutamate receptors are multimeric ligand-gated nonselective cation channels allowing the passage of $\mathrm{Na}^{+}, \mathrm{K}^{+}$or $\mathrm{Ca}^{2+}$ (69). Activation of AMPA, kainate and NMDA receptors always produces excitatory postsynaptic potentials (EPSP) (77) .

\subsubsection{NMDA receptor}

High levels of NMDA receptor-mediated $\mathrm{Ca}^{2+}$ influx during high frequency electrical stimulation enhance synaptic transmission (e.g. long-term potentiation of hippocampal neurons). In contrast, lower levels of NMDA receptor-mediated $\mathrm{Ca}^{2+}$ influx during low frequency stimulation result in a decrease of synaptic strength (e.g. hippocampal long-term depression). Excessive $\mathrm{Ca}^{2+}$ influx via NMDA receptor ion channels leads to excitotoxic cell death. The $\mathrm{Ca}^{2+}$ act as a second messenger to activate intracellular signalling cascades and may lead ultimately to the generation of nitric oxide, reactive oxygen species and thus to cell death $(92,107)$.

Traditionally, NMDA receptors are best known for their role in excitotoxicity, when overactivation of NMDA receptors causes intracellular $\mathrm{Ca}^{2+}$ accumulation in brain trauma and in neurodegenerative disorders such as Parkinson's and Huntington's diseases, amyotrophic lateral sclerosis and Alzheimer's disease (105). Overactivation of excitatory pathways is also 
observed in epilepsy $(24,50,77)$. Because of their involvement in numerous neurological disorders, NMDA receptors are also targets of therapeutic interest. Activation of NMDA receptors by glutamate is involved in the local circuit nociceptive transmission underlying the behavioural expression of hyperalgesia and allodynia $(16,83)$ and plays an important role in the development and maintenance of central sensitization, a state of long-lasting increase in synaptic transmission, and neuropathic pain at several levels (54). Consequently, the blockade of spinal NMDA recognition sites elicits antinociception in various models of persistent pain $(16,83)$.

Several subunits of the NMDA receptor are known, in particular N(MDA)R1, N(MDA)R2 and N(MDA)R3 $(32,71,105)$. The stoichiometry of NMDA receptors have not yet been established definitely, but the consensus is that NMDA receptors are tetramer that most often incorporate two NR1 and two NR2 subunits of the same or different subtypes (Fig. 2) (71). The subunit composition of NMDA receptors determines their biophysical and pharmacological properties.

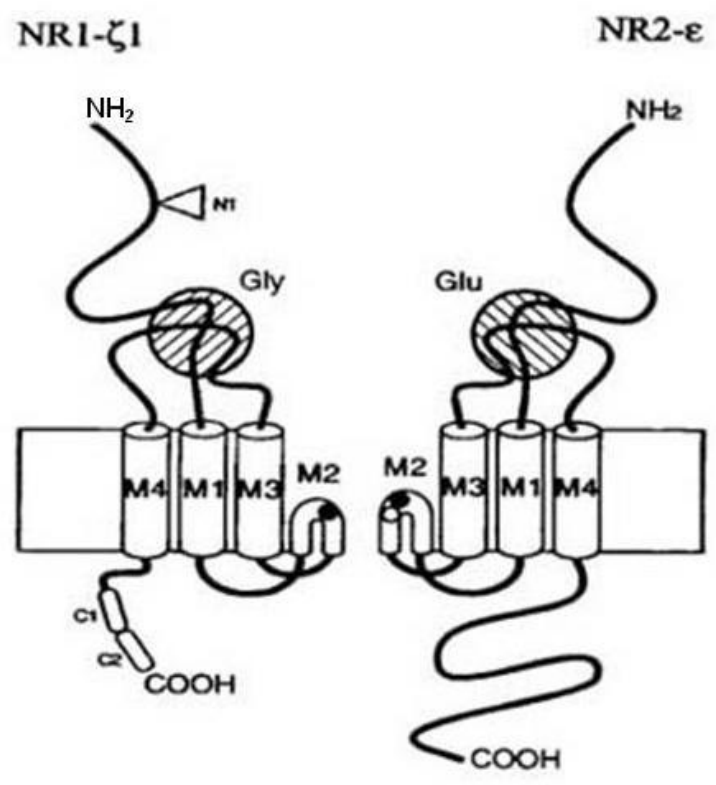

Fig. 2 Schematic representation of heteromeric NMDA receptor structure (105)

NMDA receptor subunits all share a common membrane topology characterized by

- a large extracellular $\mathrm{N}$-terminus

- a membrane region comprising three transmembrane segments (M1, M3 and M4) 
- a re-entrant pore loop (M2)

- an extracellular loop between M3-M4

- a cytoplasmic C-terminus $(21,71,105)$.

Amino-terminal domain plays an important role in subunit assembly. The two extracellular domains, namely the ligand-binding site and the amino-terminal domain, have many similarities (32). The structure of the re-entrant second membrane loop influences the permeation properties of the ion channel $(21,71)$. In the heteromeric NMDA receptor complex, the quaternary arrangement of the subunits around the central symmetry axis will govern the dimerization possibilities (71) .

The sequences of the regions lining the pore are highly conserved in the NR1 and NR2 subunits and accordingly, permeation properties as well as affinity for the pore blocker $\mathrm{Mg}^{2+}$. By contrast, incorporating the NR3 subunit markedly decreases single-channel conductance, $\mathrm{Ca}^{2+}$ permeability and $\mathrm{Mg}^{2+}$ block (71).

\subsubsection{NMDA receptor modulation}

\subsubsection{Endogenous modulators}

NMDA receptor subunits and splice variant compositions determine the sensitivity of receptors to modulation by a wide variety of compounds. Thus, several endogenous agents modulate NMDA receptors within physiological ranges and in a subunit-specific manner. These modulatory agents include glycine, kynurenic acid, polyamines, $\mathrm{Zn}^{2+}, \mathrm{Mg}^{2+}$, protons, (Fig. 3) (32). That the binding sites for these modulators are found in the amino terminal domain of their receptors and these modulatory sites allow considerable potential for pharmacological manipulations too $(21,32,40,71,105)$.

Glycine is an essential co-agonist that facilitates the actions of glutamate at submicromolar levels $(39,40,74,77)$. Thus, the maximal activation of NMDA receptor channels requires binding of both 2 L-glutamate and 2 glycine molecules $(21,32,71,105)$. Site-directed mutagenesis has identified that the glycine binding site is formed by the region preceding segment M1 of the NR1 and NR3 subunits and the glutamate binding site was shown to reside in the homologous regions of the NR2A and NR2B subunits $(21,105)$ (Fig. 2). In low extracellular glycine concentration $(<100 \mathrm{nM})$ NMDA receptor currents are potentiated by dynorphin peptides that contain glycine residues, perhaps as a result of 
proteolytic release of glycine from the parent peptide by the tissue. But dynorphin $\mathrm{A}(1-13)$ can also inhibit NMDA receptor activation in a voltage-independent manner that is noncompetitive with either NMDA or glycine but is dependent on the NR2 subunit, being greatest for NR2A. Positively charged peptides may have multiple effects on NMDA receptors, best illustrated by the effects of the dynorphin peptide (21) .

In the resting state, the NMDA receptor channel is blocked by $\mathrm{Mg}^{2+}$ ions at a site deep within the channel itself and binding of glutamate to the agonist-binding site, even in the presence of glycine, does not result in $\mathrm{Ca}^{2+}$ entry through the postsynaptic membrane. Depolarization of the membrane removes the $\mathrm{Mg}^{2+}$-mediated channel blockade and $\mathrm{Ca}^{2+}$ flux through the channel can then occur (Fig. 3) $(24,39,40,77)$.

Since AMPA and NMDA receptors are, in many cases co-localized at central synapses, the rapid activation and brief open time of AMPA facilitates the unblock of NMDA receptors by $\mathrm{Mg}^{2+}$ and thus the more slowly activating NMDA receptors participate in the long-lasting maintenance of synaptic currents $(21)$.

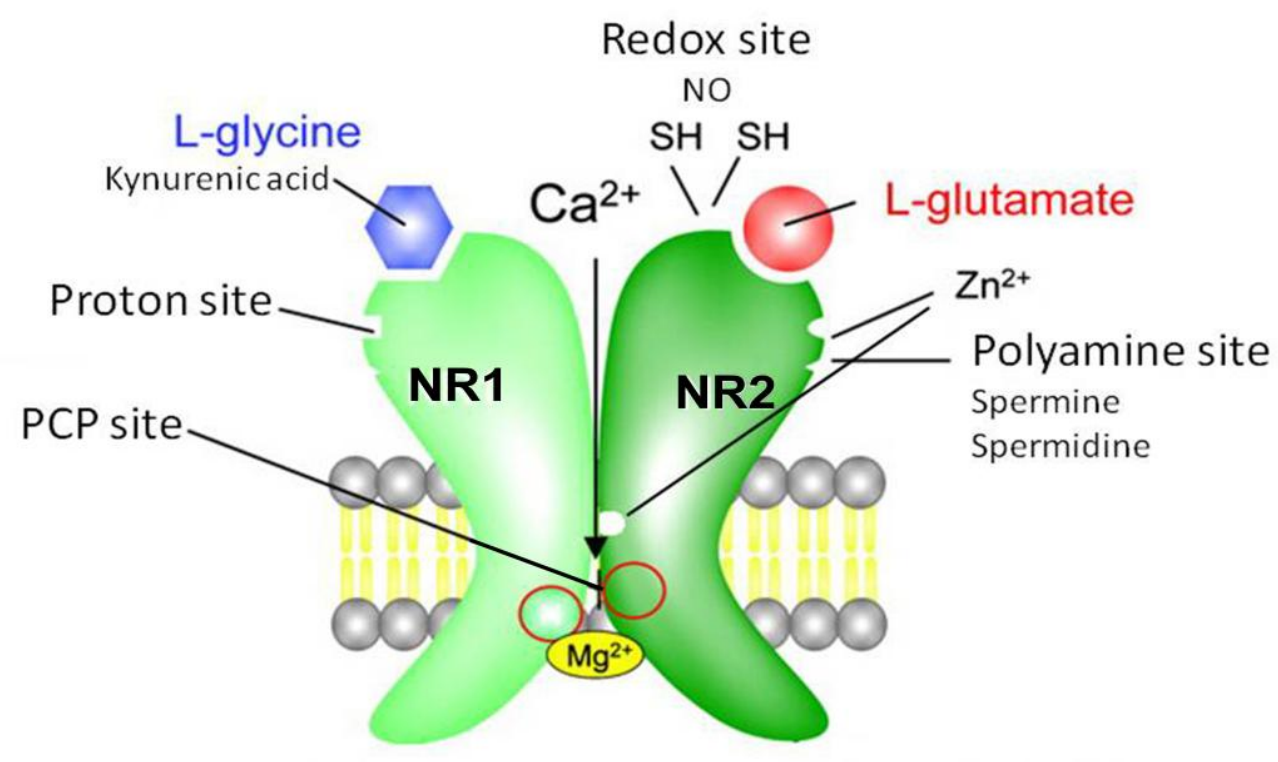

Fig. 3 Modulation sites and some endogenous ligands of the NMDA receptor (source: www.neurology.org)

In addition, $\mathrm{Mg}^{2+}$ ions are known to enter and block open glutamate receptor channels (Fig. 3). Thus, the rate of the onset of blockade is use-dependent and is accelerated by increases in open channel probability. Once bound, however, the blocker can be trapped by 
channel closure (21). Channel block by trapping blockers is slow to reverse and requires channel reactivation by agonists before the blocker can dissociate (95) .

NMDA receptor channels at physiological $\mathrm{pH}$ are tonically inhibited by proton (21). The inhibition of NMDA receptors by protons is controlled by the NR2 subunit as well as alternative exon splicing in the NR1 subunit. Mutations that influence $\mathrm{pH}$ sensitivity are broad ranging in both NR1 and NR2 subunits and include amino-terminal acidic residues, cysteine residues that may participate in disulfide bond formation residues in the extracellular M3-M4 loop as well as residues that are thought to comprise the channel pore-forming region. This latter association between pore-forming residues and $\mathrm{pH}$ sensitivity might suggest that the proton sensor is tightly coupled to the movement of the gate.

$\mathrm{Zn}^{2+}$ is concentrated at many glutamatergic synapses, and it is likely to be an endogenous allosteric modulator of NMDA receptors (71). Two types of $\mathrm{Zn}^{2+}$-binding sites are located on separate modules and inhibit NMDA receptor currents through distinct mechanisms (Fig. 3). Each NMDA receptor subunit consists of an N-terminal domain that binds allosterically active ligands including $\mathrm{Zn}^{2+}$. Voltage-independent inhibition is mediated by N-terminal domain of NR2 subunits. $\mathrm{Zn}^{2+}$ binding changes the receptor's gating kinetics but not its conductance. At high concentrations $(>10 \mu \mathrm{M})$ extracellular $\mathrm{Zn}^{2+}$ reduces opening frequency and decreases open duration $(3,21,39)$. However, at submicromolar $\left(\mathrm{EC}_{50}=0.5\right.$ $\mu \mathrm{M})$ concentrations, $\mathrm{Zn}^{2+}$ potentiates homomeric NR1 channels lacking the N1 insert in a voltage-independent manner, whereas little or no potentiation is observed for NR1 channels containing the $\mathrm{N} 1$ insert. It follows that the sensitivity of the heteromeric NMDA receptor channel to $\mathrm{Zn}^{2+}$ inhibition is determined by NR1 subunit splice variants $(21,32,71,105)$. NR2A subunit is much more sensitive to $\mathrm{Zn}^{2+}$, being inhibited in the nanomolar range $\left(\mathrm{IC}_{50}=5-30 \mathrm{nM}\right)$ by as much as 70 to $80 \%$ and NR2B subunit having low sensitivity $(\sim 1 \mu \mathrm{M})$, while $\mathrm{Zn}^{2+}$ does not bind NR2C or NR2D (3). Zinc inhibition of NR1/NR2A receptors is proton dependent. Thus, protonation of its binding residue may be critical for zinc inhibition, and/or the zinc binding domains may interact functionally and/or structurally with proton sensitive elements (32). Voltage-dependent $\mathrm{Zn}^{2+}$ inhibition of NMDA receptors is also presented at all NMDA receptor subtypes and is likely to occur within the ion channel pore and may involve the conserved asparagine residue in segment M2 of the NR1 subunit. Asparagine residues in the second transmembrane helix contribute to the narrowest portion of the permeation pathway and are critical for voltage-dependent. Glycine substitutions at these critical positions increase pore diameter and reduce channel sensitivity to voltage-dependent 
block by orders of magnitude. This asparagine residue is also involved in the $\mathrm{Ca}^{2+}$ permeability and the $\mathrm{Mg}^{2+}$ block of NMDA receptor channel $(3,32,105)$.

The redox modulatory site of NMDA receptor channel exists in equilibrium between fully reduced (thiol, R-SH) and fully oxidized (disulphide, R-S-S-R) states (105). This site contains two labile cysteine residues on the NR1 and NR2 subunits where sulphydryl groups of subunits may interact with nitric oxide (NO) derivatives to modify channel function $(21,39)$ (Fig. 3). Lei et al. demonstrated that NO can form a disulfide bond(s), which is thought to constitute the redox modulatory site of the receptor, resulting in a relatively persistent blockade of NMDA responses (52). These reactions with NO can afford protection from NMDA receptor-mediated neurotoxicity. This is a new pathway for NO regulation of physiological function. It is not via cGMP, but instead involves reactions with membranebound thiol groups on the NMDA receptor-channel complex. The redox site has physiological and pathological importance. Among the most prominent of these are free radicals, superoxide and hydroxyl radicals, which suppress NMDA receptor activation.

Effects of polyamines on NMDA receptors were first reported in 1988 (80). The polyamines putrescine, spermidine and spermine are present in almost all cells and have important roles in protein synthesis, cell division and cell growth. Spermine and spermidine are present in high concentrations in the nervous system, and uptake and depolarization induced release of polyamines from brain slices has been reported $(30,85,100)$. They are organic polycations that are protonated at physiological $\mathrm{pH}$ and can potentially interact with a variety of cellular targets including nucleic acids and proteins (100). Polyamines can stimulate NMDA receptor function to a greater degree at low glycine concentrations than at saturating glycine concentrations. This stimulation reflects approximately a 3 -fold increase in glycine affinity. Both glycine-independent and glycine-dependent forms of potentiation of NMDA receptor function are influenced by the NR2 subunit (Fig. 3). However, whereas glycine-dependent potentiation occurs at NR2A- and NR2B-containing receptors, glycineindependent potentiation is observed exclusively at receptors that incorporate the NR2B subunit. The glycine-independent form of potentiation has been suggested to arise from the relief of tonic proton inhibition at physiological $\mathrm{pH}$. That is, polyamines shift the $\mathrm{pKa}$ of the proton sensor to acidic values, reducing the degree of tonic inhibition at physiological $\mathrm{pH}$, which appears as a potentiation of function $(21,100)$. Spermine was also reported to relieve voltage-independent $\mathrm{Zn}^{2+}$ inhibition of the heteromeric NMDA receptor channel $(80,85)$. Polyamines also have inhibitory effects. The inhibitory effects can be divided into a decrease 
in the affinity for glutamate and strongly voltage-dependent inhibition $(21,100,105)$. Extracellular spermine can block NMDA channels at negative membrane potentials, and at extreme negative potentials, spermine can permeate the NMDA channel to pass into the cell (100). Single-channel studies indicated that the enhancement of NMDA receptor current by spermine at low concentration $(10 \mu \mathrm{M})$ was due to an increase in opening frequency of NMDA receptor single channels, whereas at higher concentrations $(1 \mathrm{mM})$ spermine decreased average open duration and conductance of the NMDA single-channel currents at negative holding potentials $(85,86)$.

Kynurenic acid is a metabolite of the tryptophan metabolism with a complex pharmacology (92). It is able to antagonise non-NMDA as well as NMDA receptor activation, because it had an especially high affinity at the glycine site and may even distinguish subpopulations of kainite receptors therefore, it can possess neuroprotective activity (Fig. 3) (92). The kynurenine pathway is present primarily in the glial cells population in the CNS such as microglia. When these cells activated by immunogenic stimuli such as bacterial lipopolysaccharide or interferon- $\gamma$, they are able to generate up to 1000 times the basal levels of kynurenines. Because of activating the pathway, there is an increased generation of excitotoxicity compounds such as quinolinic acid, an endogenous agonist at NMDA receptors and 3-hydroxykynurenine. An alternative strategy to the direct blockade of glutamate receptors is to modify activity in the kynurenine pathway, changing the balance between the generation of quinolinic acid and kynurenic acid. Inhibition of the enzymes kynurenine hydroxylase and kynureninase by nicotinylalanine results in a decrease in the levels of endogenous quinolinic acid and an increase of kynurenic acid. Quinolinic acid acts selectively at NMDA receptors containing NR2A and NR2B subunits, with massive calcium entry into neurons and astrocytes (76). The in vivo overstimulation of NMDA receptors by quinolinic acid causes an early impairment of the sarco/endoplasmatic reticulum $\mathrm{Ca}^{2+}$-ATPase pump which may result in important disturbances in intracellular $\mathrm{Ca}^{2+}$ signalling (56) .

NMDA receptor-induced $\mathrm{Ca}^{2+}$ influx has been shown to promote rapid inactivation of NMDA receptor (63). This calcium-dependent inactivation (CDI) serves as a negative feedback control system to regulate $\mathrm{Ca}^{2+}$ influx. CDI is unaffected by ATP, phosphatase, inhibitors, and other agents that affect protein phosphorylation (87) . CDI is regulated by the actin cytoskeleton. Actin destabilizing agents such as the cytochalasins specifically eliminate CDI, suggesting that the NMDA receptors may be associated with the actin. Zhang et al. showed that, the calcium binding protein, calmodulin, binds to two sites (CBS1 and CBS2) on 
the $\mathrm{C}$ terminus of the NR1 subunit of the NMDA receptor (25). Calmodulin binding to the $\mathrm{C}$ terminus of the NR1 subunit decreases the open probability on NMDA receptor channels (25). CB1 region of the NR1 subunit also interacts with $\alpha$-actinin2, an actin-associated protein and that calmodulin can compete for $\alpha$-actinin 2 binding to the NR1 subunit. Zhang et al. demonstrated that deletions or point mutations of $\mathrm{CB} 1$ in the NR1 C terminus substantially block CDI (107). Deletion of CB2 has no effect on CDI. In addition, intracellular infusion of a calmodulin inhibitory peptide blocks CDI of both recombinant and native NMDA receptors in hippocampal neurons. Intact actin cytoskeleton is required for CDI of NMDA receptors because the NMDA receptor might directly interact with a cytoskeletal protein $(\alpha-$ actinin2) that dissociates from the channel in a $\mathrm{Ca}^{2+}$-dependent manner, leading to inactivation. Moreover, $\alpha$-actinin 2 co-localizes with NMDA receptors at excitatory synapses (107)

\subsubsection{Exogenous modulators}

Several drugs acting on NMDA receptors may be suitable for the treatment of neuropathology, others cause severe cognitive and behavioural disturbances. NMDA receptor antagonists can divide four categories: competitive antagonists bind to and block the glutamate binding site (e.g. selfotel); glycine antagonists bind to and block the glycine site (e.g. kynurenic acid); non-competitive antagonists block the ion channel by binding to a site within it (e.g. MK-801, memantine, ketamine) (Fig. 4).

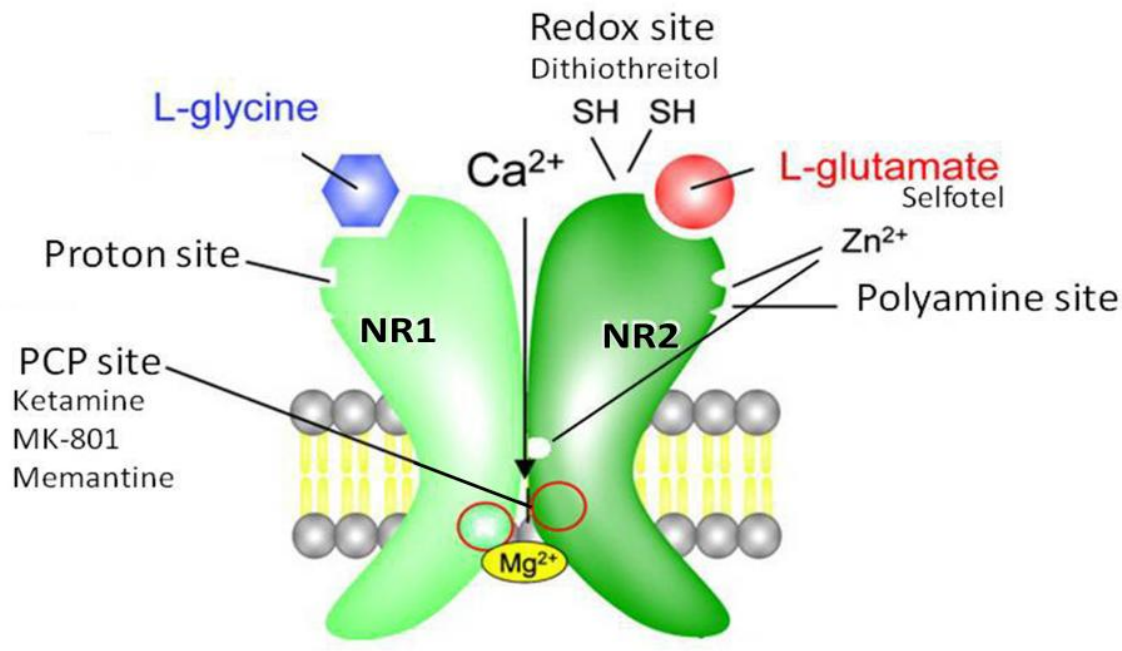

Fig. 4 Modulation sites and exogenous ligands of the NMDA receptor (source: www.neurology.org) 
Reducing agents such as dithiothreitol can potentiate NMDA receptor channels, while oxidizing agents such as 5-5'-dithiobis-2-nitrobenzoic acid are inhibitory (92, 105) (Fig. 4).

At intoxicating concentrations, ethanol is another non-competitive NMDA receptor antagonist, and trichloroethanol, the active metabolite of the hypnotic chloral hydrate, also blocks NMDA receptors noncompetitively at anaesthetic concentrations. Ethanol molecules accommodate into a physical cavity in NMDA receptors, which is reachable from lipophilic milieu favours entry and affinity/efficacy of longer-chain alcohols on the receptor (68). Block by ethanol was more potent with the NR2A or NR2B than the NR2C subunit $(21,68)$, but the degree of block was not affected by $\mathrm{pH}, \mathrm{Zn}^{2+}$ or redox state of the receptor (21). Elevating extracellular $\mathrm{Mg}^{2+}$ from close to zero $\mathrm{Mg}^{2+}$ to more than physiological concentrations, increases ethanol sensitivity of NMDA receptors (60). Ethanol inhibition is stronger if calcium and calmodulin-dependent inactivation of NMDA receptors are allowed to function properly (4). Hoffman et al. found that ethanol had a potent and selective effect on the NMDA receptor in the primary cultures of cerebellar granule cells (36). In these cells, glutamate acting at kainite and NMDA receptors increases the cGMP level. This effect might be mediated via an action on agonist-stimulated calcium influx. These biochemical data were corroborated by electrophysiological experiment showing that ethanol was a very potent inhibitor of NMDA-gated currents in hippocampal cell culture (36) .

Selfotel (CGS 19755) is a competitive NMDA antagonist, it has proved to be neuroprotective in different animal models of global ischemia, focal ischemia and brain trauma (73) (Fig. 4).

Phencyclidine (PCP) is a dissociative anaesthetic, antagonizes NMDA-evoked responses non-competitively, and has no effects on the binding of glutamate to the NMDA receptor recognition site (26). PCP-likes drugs (phencyclidine, ketamine or tiletamine) block NMDA receptor responses by binding to a site, which is downstream from the transmitter recognition site possibly an activated or opened configuration of the channel complex (26) (Fig.4).

MK-801 (dizocilpine) binds at PCP's binding site of NMDA receptors and blocks it in a use- and voltage-dependent manner. Thus, the channel must open for the drug to bind inside it, preventing the flow of ions, including an influx of $\mathrm{Ca}^{2+}$, through the channel (Fig. 4). MK801 is a well-known neuroprotectant in models of stroke, trauma, Parkinsonism and organophosphate-induced seizures (50). Despite this, MK-801, like other PCP receptor 
ligands, such as phencyclidine, ketamine or tiletamine, induces psychotic behaviour and neuronal degeneration. MK-801 exposure causes neuronal degeneration in axon terminals, increases glucose metabolism, induces cytoplasmic vacuoles, heat shock protein and necrotic cell death in neurons of the rodent in many brain areas (38).

Memantine is an uncompetitive NMDA receptor antagonist, which has been used clinically for years for the treatment of Parkinson's disease, spasticity, and dementia (55). Memantine is able to block the excitotoxic effects of NMDA receptor overactivation without altering normal synaptic transmission because it has a low-affinity to the NMDA receptors and has a relatively rapid off-rate from the channel (51). Memantine has been shown to be less voltage-dependent than $\mathrm{Mg}^{2+}$, which allows memantine to continue to block the channels under relatively depolarized conditions. In addition, studies have found that memantine effectively blocks NMDA receptor activity in the presence of prolonged elevations of glutamate concentrations (13) (Fig. 4).

\subsubsection{Ketamine}

Ketamine [2-(O-chlorophenyl)-2-methylamino cylohexanone] (MW: 238), a non-competitive NMDA receptor antagonist. Its effects are mediated primarily by non-competitive antagonism at the NMDA receptor $\mathrm{Ca}^{2+}$ channel pore and these effects appear to be the primary mechanisms of the anaesthetic and analgesic action of ketamine in rodents and humans $\{139$, 140, 141, 168, 171 . Ketamine acting on the phencyclidine site of NMDA receptor and binds to opioid and acetylcholine receptors also, but the affinity of ketamine for these receptors is lower than that for the NMDA receptors $(43,82)$. Ketamine produces a so-called 'dissociative' anaesthetic state, which has been described as a functional and electrophysiological inhibition of thalamocortical pathways and stimulation of the limbic system $(49,64,98)$.

It was synthesized as Ketalar in 1962, first used on American soldiers during the Vietnam War (70) . The racemic mixture was approved for general clinical use in 1970, but its clinical usefulness has been limited because of its cardiovasvular-stimulating properties and high incidence of disturbing emergence reactions (98). The molecular structure contains a chiral center at C-2 of the cyclohexanone ring so that there are two optical isomers (enantiomers) of 
the ketamine molecule: $\mathrm{S}(+)$-ketamine and $\mathrm{R}(-)$-ketamine (Fig. 5). The $\mathrm{S}(+)$ ketamine has a three- to four-fold greater affinity compared the $\mathrm{R}(-)$ form on the NMDA receptor $(49,70,97,98)$. Commercially available racemic ketamine preparations contain equal concentrations of the two enantiomers $(42,43,49,70,98)$.

Ketamine is metabolized extensively by hepatic drug-metabolizing enzyme systems. The major pathway of biotransformation involves $\mathrm{N}$-demethylation of ketamine to form norketamine that can then be hydroxylated to form hydroxyl-norketamine compounds, which in turn can be conjugated to more water-soluble glucuronide derivatives $(42,49,98)$. The primary metabolite norketamine is only one-third to one-fifth as potent as the original compound, but it may be involved in the prolonged actions of ketamine $(49,70,98)$. The metabolites of norketamine are excreted by the kidneys (49) .

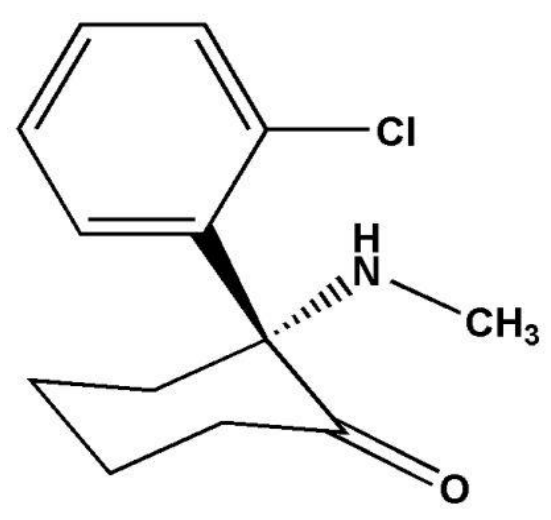

(S)-Ketamine

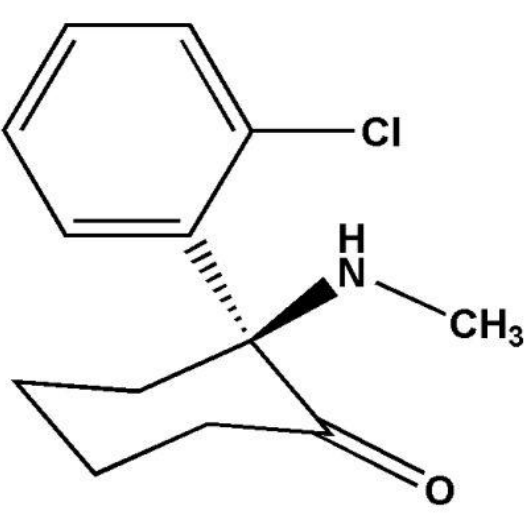

(R)-Ketamine

Fig. 5 Stereoisomers of ketamine

Ketamine has high lipid solubility and crosses the blood-brain barrier easily. It acts in the CNS but it also has local anaesthetic properties $(34,70,98)$. Smidt et al. in 1985 were the first who examined the effect of the systemic treatment of ketamine in acute pain test in rodents (90). They found that the systemic ketamine (160 mg/ $\mathrm{kg}$ intraperitoneal) significantly increased tail flick (TF) latency and this effect was prevented by naloxone (3 $\mathrm{mg} / \mathrm{kg}$ intraperitoneal). Intraperitoneal ketamine treatment attenuates established neuropathic nociceptive behaviours including mechanical allodynia and hyperalgesia, cold allodynia, spontaneous pain and cold stress-induced pain in rats (79). Ryder et al. showed that $S(+)$ 
enantiomer is three times more potent than $\mathrm{R}(-)$ enantiomer in phenylquinone writhing test in mouse (88). The intrathecal administration of racemic ketamine produces only weak or no analgesic effects against acute pain, such as that in the TF test (57), although it reduces the hyperalgesic effect of a hind paw carrageenan injection (83) and of nerve injury (106).

There have been only a few published reports on the analgesic properties of the individual optical isomers of ketamine after systemic administration $(59,82)$, but no reports were available on their analgesic properties after intrathecal administration. 


\section{AIMS}

\section{Experiment I.}

The spinal cord is an important neuronal structure for pain transmission, and it is one of the pharmacologic sites of action for the antinociceptive effects of different drugs. Subarachnoid administration of local anaesthetics is widely used for providing surgical anesthesia, postoperative analgesia and treatment of chronic pain. A single injection of local anaesthetics into the epidural or intrathecal space has a limited duration of action. Catheterization techniques have been developed to prolong anaesthetic effect. In our previous studies we observed side differences after intrathecally administered drugs in pain tests of rats and only few authors have noted that the position of the catheter tip in the transverse plane is one of the important factors governing the successful subarachnoid spread of a solution $(1,33,99)$. The particular aims of the work were:

1. To observe the side differences in the motor and sensory disturbances after intrathecal administration of different doses of the local anaesthetic lidocaine in rats.

2. To determine the distribution of intrathecal catheter tips at longitudinal and transversal plane.

3. To investigate the correlation between the location of the catheter tip, the motor and sensory disturbances after intrathecal administration of a small dose of lidocaine to a large number of animals. Such a correlation might be very important, especially if small doses of administered drugs and their effects are investigated on both sides.

\section{Experiment II.}

More than $50 \%$ currently used drugs are chiral compounds and about $90 \%$ of them have been marketed and clinically administered as racemates, which contain an equal mixture of two enantiomers. Enantiomers are well known to show the differences in pharmacodynamics, which originate from the stereostructure-specific actions. One enantiomer may be preferred over its enantiomeric counterpart or a racemic mixture because it may increase beneficial activity and may decrease adverse toxicity, indicating the clinical advantage of using a single enantiomer. Such enantiomeric drugs include general and local anaesthetics, sedatives, 
hypnotics, anti-inflammatory drugs, analgesics and $\beta$-adrenergic antagonists. The particular aims of our work were:

4. To investigate the antinociceptive effect of intrathecal administration racemic ketamine on carrageenan-induced thermal hyperalgesia in paw withdrawal test (PWD).

5. To investigate the antinociceptive effect of intrathecal administration $\mathrm{S}(+)$ - and $\mathrm{R}(-)$ ketamine enantiomer on carrageenan-induced thermal hyperalgesia.

6. To investigate the antinociceptive effect of intrathecal administration $S(+)-$ and $R(-)$ ketamine enantiomer on acute heat pain sensitivity in TF test.

7. To investigate the antinociceptive effect of intrathecal administration $\mathrm{S}(+)$ - and $\mathrm{R}(-)$ ketamine enantiomer on acute heat pain sensitivity in hot-plate (HP) test. 


\section{MATERIALS AND METHODS}

\subsection{Animals}

After institutional approval had been obtained from the Animal Care Committee of the University of Szeged, Faculty of Medicine, male Wistar rats weighing (160-330 g) were studied $(n=448)$.

All experiments were performed in freely moving animals during the same period of the day (8:00 AM to 1:00 PM) to exclude diurnal variations in pharmacological effects. The animals were randomly assigned to treatment groups, and the observer was blinded to the treatment administered. In order to reduce the stress of animals, they were habituated to the hand before experiments.

\subsection{Intrathecal catheterization}

For spinal drug administration, the rats were surgically prepared under ketamine and xylazine anaesthesia (72 and $8 \mathrm{mg} / \mathrm{kg}$ intraperitoneally, respectively). Polyethylene tubing was sterilized with absolute alcohol than was rinsed with sterile distilled water before use. An intrathecal catheter (PE-10: I.D. $0.28 \mathrm{~mm}$; O.D. $0.61 \mathrm{~mm}$ ) was inserted through a small opening in the cisterna magna and passed $8.5 \mathrm{~cm}$ caudally into the intrathecal space, as described previously (104). After surgery, the rats housed individually, had free access to food and water and were allowed to recover for at least 3 days before use. Rats exhibiting postoperative neurologic deficits (approximately 10\%) were excluded.

\subsection{Drugs}

The drugs used were ketamine hydrochloride (Ketalar; Pfizer Med-Inform, Vienna, Austria), xylazine hydrochloride (Rompun; Bayer, Leverkusen, Germany), phenobarbital sodium (Hungaropharma Rt., Budapest, Hungary), lidocaine 2\% and 10\% (Egis, Budapest, Hungary) carrageenan- $\lambda$ (Sigma-Aldrich Kft, Budapest, Hungary), racemic ketamine [SR( +)-ketamine], $\mathrm{S}(+)$ - ketamine, and R(-)-ketamine (all ketamines were Parke-Davis; a generous gift from Gödecke Ltd., Vienna, Austria). 


\subsection{Intrathecal administration}

Intrathecally applied drugs were dissolved in sterile, physiological saline freshly prepared on the day of the experiment and given in single (experiment I.) or cumulative (experiment II.) doses. Drugs were injected intrathecally over $30 \mathrm{~s}$ in a volume of $5 \mu \mathrm{l}$, followed by a $10 \mu \mathrm{l}$ flush of physiological saline.

\subsection{Carrageenan-induced inflammation}

Unilateral inflammation was induced by intraplantar injection of $3 \mathrm{mg}$ of carrageenan in 0.1 $\mathrm{ml}$ of physiological saline into the right hind paw. The carrageenan solution was prepared freshly on the day of the experiment.

\subsection{Pain tests}

The nociceptive sensitivity was assessed by using tail flick, hot plate and paw withdrawal techniques with moderate stimulus intensities.

\subsubsection{Tail flick test}

Janssen et al. have described the TF technique, as a tail withdrawal response (41). The rats were covered with a towel on the measuring surface and were held at rest. The time was started by foot switch when lower $5 \mathrm{~cm}$ portion of their tail were immersed in hot water $\left(51.5^{\circ} \mathrm{C}\right)$ and was stopped when the animals reacted by flicking their tails (cut off time: $20 \mathrm{~s}$ ). The reaction time in the TF test is the elapsed time between immersion of tail and tail withdrawal response.

\subsubsection{Hot-plate test}

A clear Plexiglas chamber was situated on the surface of hot plate. All animals were placed individually into the chamber. The latency of licking one of the hind paws or jumping was measured. The surface temperature of the HP was maintained $52.5{ }^{\circ} \mathrm{C}$; this temperature was verified by periodically monitoring the surface of the HP with a contact thermometer. Animals that failed to react to the thermal stimulus within 60 seconds were removed from the HP surface and assigned 60 seconds response latency. No tissue damage was apparent in subjects that failed to react prior to the 60 second cut off time. 


\subsubsection{Paw withdrawal test}

Nociceptive sensitivity of the hind paws was determined by studying the unilateral PWD latency in response to radiant heat stimulation (29). All rats were placed individually on a glass shelf in rectangular chambers made of clear Plexiglas and were allowed to acclimatize to their surroundings for $20 \mathrm{~min}$. A movable radiant heat source powered by a constant current supply was focused on the glass from below. A single switch activated both the radiant heat source and an electronic timer capable of measuring 0.1-s intervals. After the animal had settled in place on the glass shelf and it was ensured that the plantar skin was in contact with the glass, the heat source was positioned under the plantar surface of the desired hind paw. The heat source was turned on when the hind limb was withdrawn from the glass shelf. The cut off time was set at 20 s to avoid any thermal injury.

\subsection{Assessment of motor impairment}

The motor impairment was determined in two ways:

\subsubsection{Determination of motor paralysis}

The motor impairment was determined after lidocaine administration. Clubbing of the hind paw and the inability to stand on one of the hind limbs were indicative of motor block $(\mathrm{n}=$ 376).

\subsubsection{Grip-strength test}

The second method was to determine the grip strength. We used an apparatus designed for the measurement of unilateral hind limb grip strength (28). The device consisted of a horizontally mounted, 6- $\mathrm{mm}$ mesh stainless steel (0.6-mm diameter) screen attached to an electronic force-gauge dynamometer. A rat was positioned on a Plexiglas bench adjacent to the screen so that the two forelimbs and the one of the hind limbs rested on the bench and the other hind limb rested on the screen. For each test, the rat's tail was pulled backward in a smooth but firm manner until the rat's grip on the screen was broken. The mean of the results of three consecutive attempts (the duration of the test was approximately $20 \mathrm{~s}$ ) was used for statistical analysis. Grip-strength testing was performed before and within 5 min after lidocaine administration $(n=23)$. 


\subsection{Localization of the catheter tip}

After experimental use rats $(\mathrm{n}=376)$ were killed with an overdose of phenobarbital sodium, and laminectomies were performed between vertebrae C7 and L5 without removing the spinal cord from the vertebrae. Before laminectomies $5 \mu \mathrm{l}$ of methylene blue was injected into the cannula, and the level and side positions of the catheter tip were determined. This method also helped us to visualize whether the catheter tips were placed epidural, subdural, or inside the spinal cord. Catheter tip positions in the longitudinal plane were identified by the level of the vertebral body. In the transverse plane, the subarachnoid space was subdivided into four parts — left, right, dorsal, and ventral — as shown in Figure 6. It has been postulated that, if the tip of the catheter is closer to one side, the effect of the drug should be more effective on that side. Therefore, in contrast with Asato et al. (5), we used the dorsal or ventral categories only when the tip of the catheter was very close to the midline.

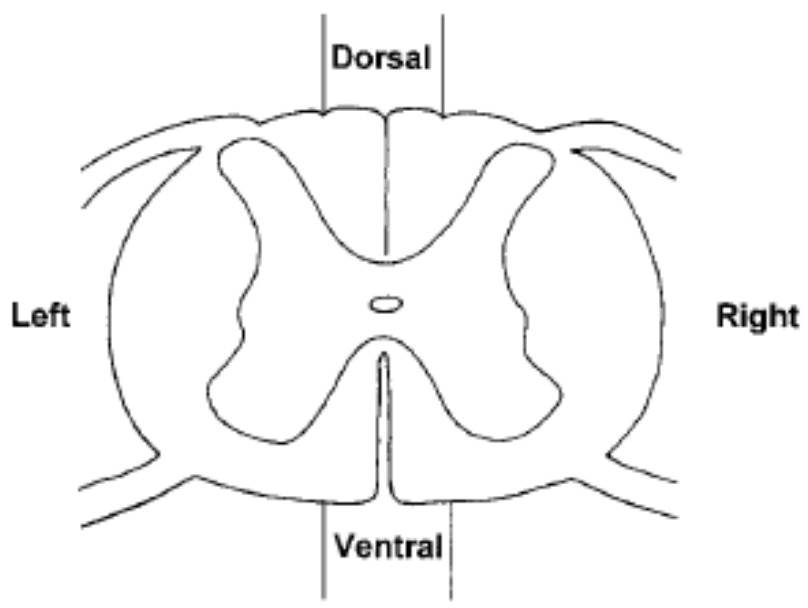

Fig. 6 Schematic diagram of the categorization of the transversal plane of the rat subarachnoid space.

\subsection{Experimental protocols}

The following steps were in all experiments:

1. Insertion of the intrathecal catheter,

2. One day after surgery: visual control of the motor impairment,

3. 3-5 days after surgery: intrathecal drug administration, and pain tests implementation. 


\section{Experiment I.}

In the first group of animals, we determined the time response curve of $100 \mu \mathrm{g}$ of lidocaine $(\mathrm{n}=45)$. PWD testing was performed before and 1, 5, 10, and $20 \mathrm{~min}$ after lidocaine administration. In the second group of animals, we examined the possibility of correlation between the side position of the catheter tip and the side differences in the paralysis and PWD latencies after $100 \mu \mathrm{g}(\mathrm{n}=264)$ or $500 \mu \mathrm{g}(\mathrm{n}=112)$ of lidocaine.

The first step was the determination of the motor block, and then we measured the PWD latencies in the thermal testing apparatus within $5 \mathrm{~min}$. The person conducting the behavioural test was blinded to the administered dose.

In the third group of animals $(\mathrm{n}=23)$, the effect of $100 \mu \mathrm{g}$ lidocaine on the hind paw grip strength was investigated. We also studied the possibility of a correlation between the side differences in the grip strength and the side position of the cannula tip.

After all experiments, the side position of the catheter tip was determinate.

\section{Experiment II}

In the first group of animals, we examined the antinociceptive effect of cumulative doses of ketamine isomers on the PWD test. First we obtained baseline PWD latencies (precarrageenan values at - $180 \mathrm{~min}$ ), and the next step was the intraplantar carrageenan injection into the right hind paw.

Three hours after carrageenan injection, paw withdrawal latencies were obtained again (postcarrageenan baseline values at $0 \mathrm{~min}$ ), then 10 and $30 \mathrm{~min}$ after the drug injections (10, 50 , and $100 \mu \mathrm{g}$ ketamine isomers). Values from 10 and $30 \mathrm{~min}$ after each drug injection were averaged to obtain one value for each drug dose.

In the second group of animals, we examined the antinociceptive effect of cumulative dose of ketamine isomers on the HP and TF tests. The baseline latencies were obtained immediately before ketamine injection, then the measurement was repeated 10 and 30 min after the drug injections $(10,100$, and $500 \mu \mathrm{g}$ ketamine isomers) and $60 \mathrm{~min}$ after last administration of ketamine isomers $(500 \mu \mathrm{g})$.

\subsection{Data analysis}

Data are given as means \pm SEM. Data sets were examined with analysis of variance and correlation analysis by using STATISTICA software (StatSoft Inc., Tulsa, OK). 
The statistical significance of different enantiomers (treatment) and doses was assessed by two-way analysis of variance (ANOVA). One-way ANOVA was used to compare treatment effects, with the Newman-Keuls test for post hoc comparison for differences between means. A level of $\mathrm{P}<0.05$ was considered significant. 


\section{RESULTS}

\section{Experiment I}

The baseline PWD was $10.0 \pm 0.20 \mathrm{~s}$ for the right hind paw and $9.8 \pm 0.21 \mathrm{~s}$ for the left hind paw; the difference between the two sides was not significant. Regarding the time course of the effect of $100 \mu \mathrm{g}$ of lidocaine, the PWD latency was the longest between 1 and $5 \mathrm{~min}$, and the effect was short (Fig. 7). In further experiments, therefore, the anaesthetic and motor effects of lidocaine were determined within 5 min after the intrathecal injection.

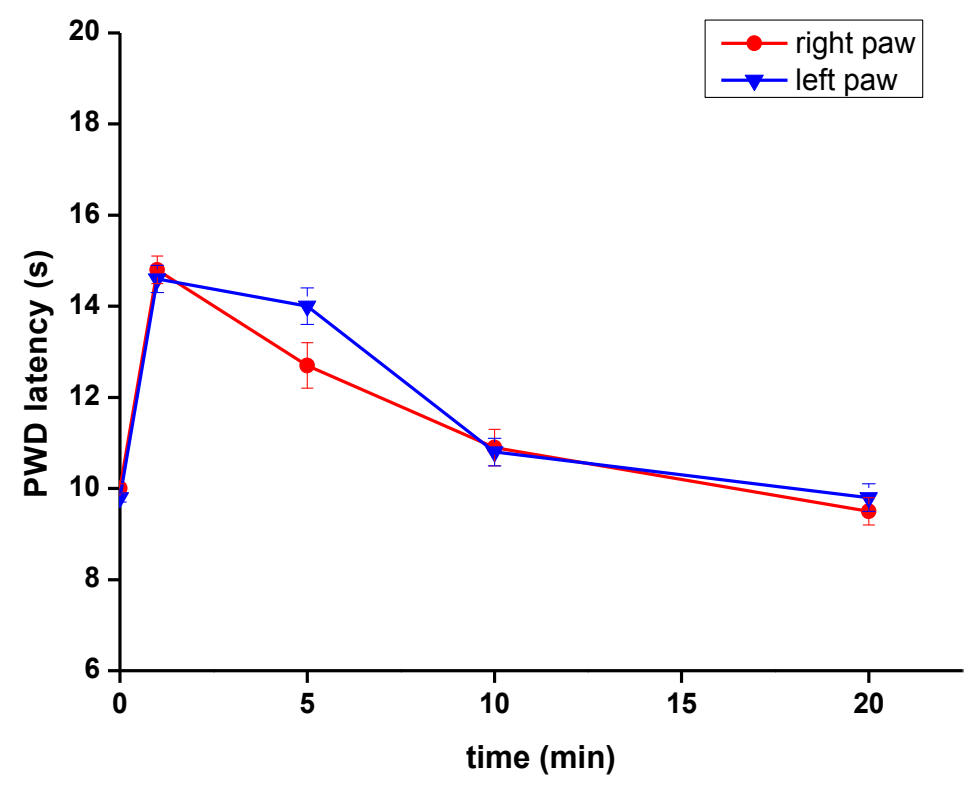

Fig. 7 Time-dependent effect of $100 \mu \mathrm{g}$ lidocaine on the PWD test.

Both sensory and motor impairments depended on the dose of lidocaine applied (Fig. 8). Regarding the pain threshold changes, the distribution of the PWD latencies show that, in contrast with $100 \mu \mathrm{g}$ of lidocaine, $500 \mu \mathrm{g}$ of lidocaine caused high (18-20 s) PWD latencies in a larger percentage (Fig. 8 A-D). $100 \mu$ g lidocaine caused maximal effect on both sides in $3(1.1 \%)$ of 264 animals, whereas the larger dose of lidocaine did so in 45 (40.2\%) of 112 animals. Similar to the PWD results, whereas $100 \mu \mathrm{g}$ of lidocaine caused paralysis on both sides in $4.4 \%$ of the animals, $500 \mu \mathrm{g}$ of lidocaine did so in $88.4 \%$ of the animals (Fig. $8 \mathrm{E}$ and F). It was also observed that the numbers of left and right side paralyses were similar. 
Accordingly, to examine the correlation between the location of the catheter tip and the motor paralyses, we used $100 \mu \mathrm{g}$ of lidocaine in further experiments.
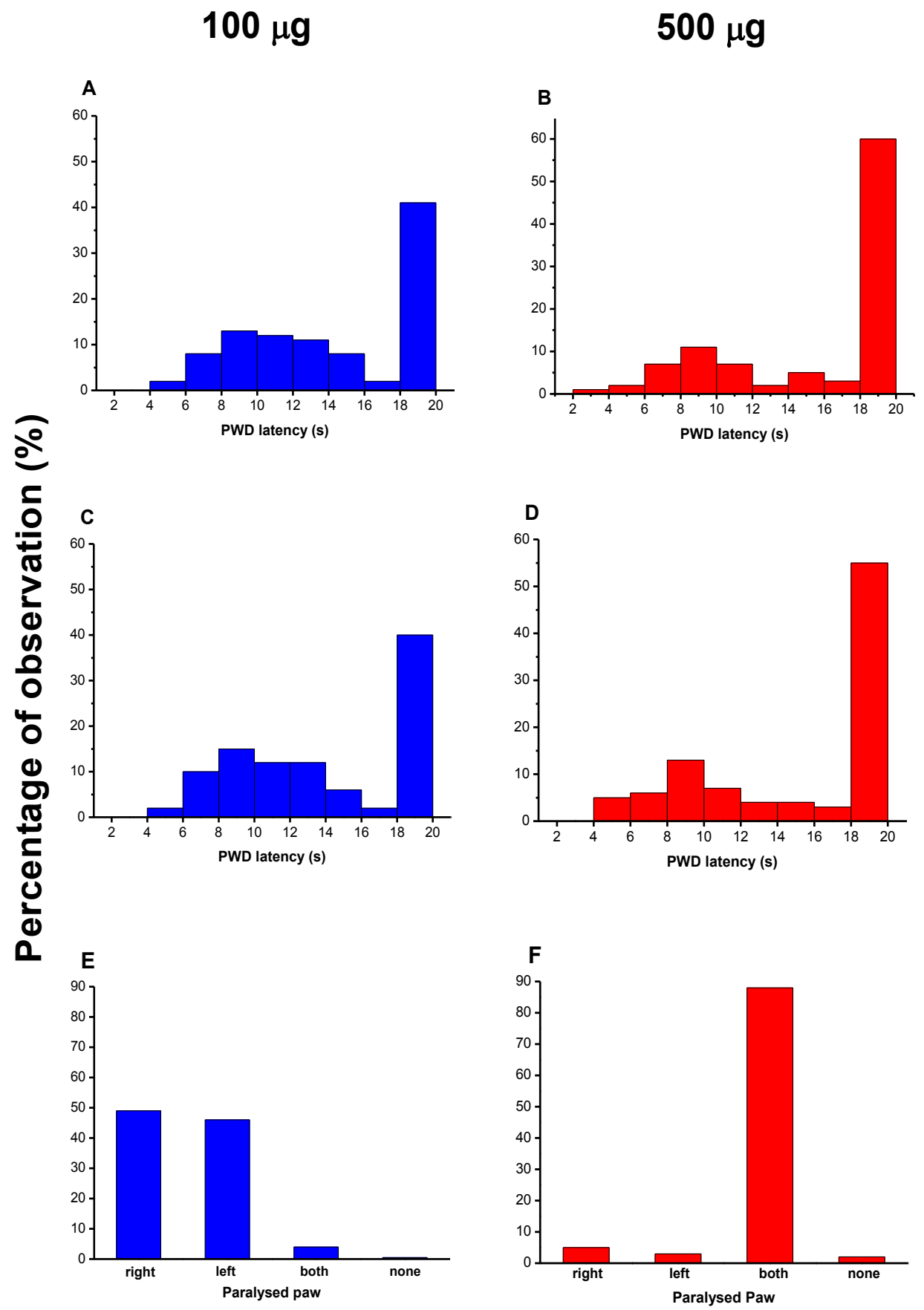

Fig. 8 Histograms showing the distribution of paw withdrawal (PWD) latencies (A and B right paw; $C$ and D left paw) and the distribution of motor paralysis after $100 \mu \mathrm{g}(\mathrm{n}=264)(\mathrm{E})$ and $500 \mu \mathrm{g}$ of lidocaine $(\mathrm{n}=112)(\mathrm{F})$. 
As regards the $8.5-\mathrm{cm}$ length of the catheter, it served to place the tip between vertebrae T12 and L2. The level of the tip correlated significantly with body weight $(r=0.4, \mathrm{P}<0.05)$ (Fig. 9).

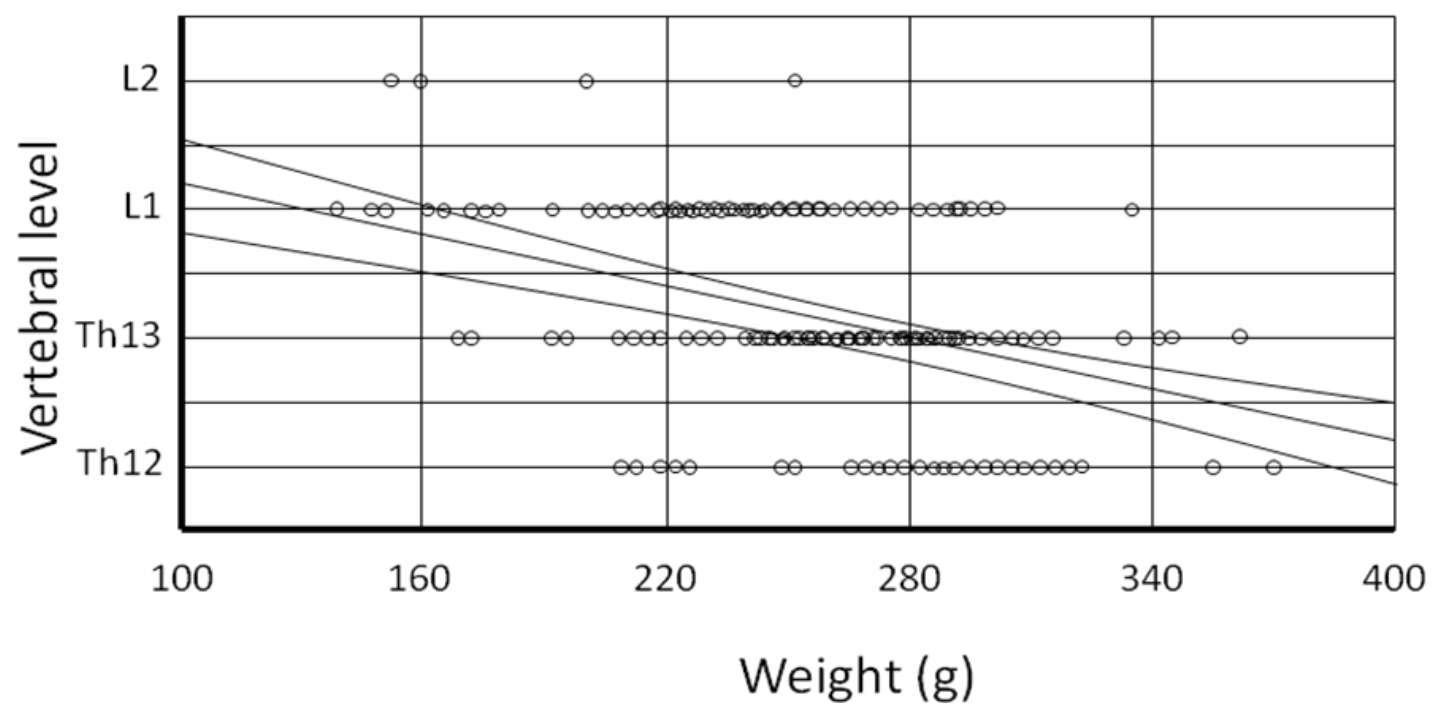

Fig. 9 Correlation between weight and the level of the catheter tip in the longitudinal plane (n =376).

The catheter tips were found subdurally in most cases, but in 7 animals, without any motor impairment, the catheter penetrated the cord and the catheter tip was located inside the spinal cord. The catheter tip was located on the left side in $39.6 \%$, on the right side in $39.4 \%$, dorsally in $14.4 \%$, and ventrally in $4.84 \%$ of the 376 rats. Therefore, in $79 \%$ of the cases, the catheter tip was situated on one side (left or right) (Fig. 10). 


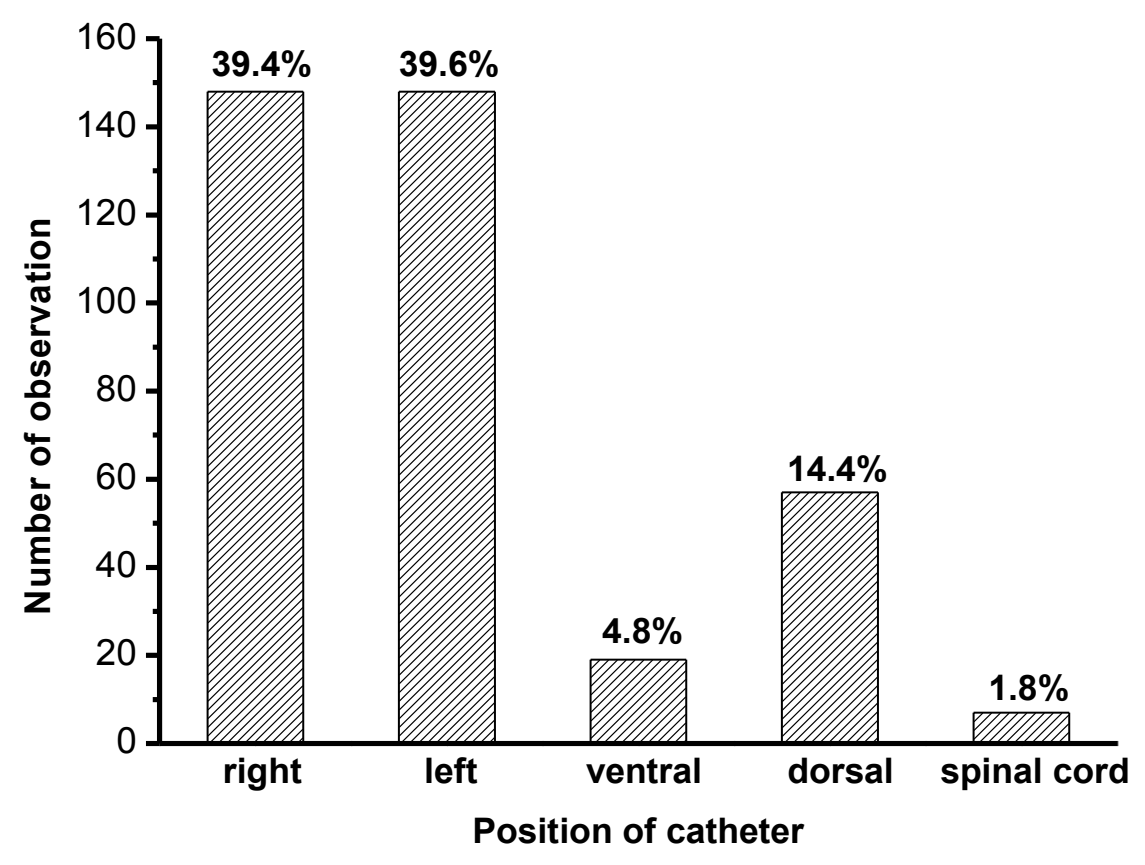

Fig. 10 Distribution of the position of the catheter tip in the transversal plane $(n=376)$.

It has been observed that the side on which the catheter tip was located correlated significantly with the side on which motor paralysis was observed $(n=264, r=0.77)$ (Fig. 11 A) and also with the PWD latencies $(n=264 ; r=0.60$ and $r=0.67$ for the right and the left side, respectively) (Fig. $11 \mathrm{~B}$ and C). There was also a close correlation between the motor paralysis and the PWD latencies $(n=193 ; r=0.75$ and $r=0.82$ for the right and the left hind paw, respectively). 
A

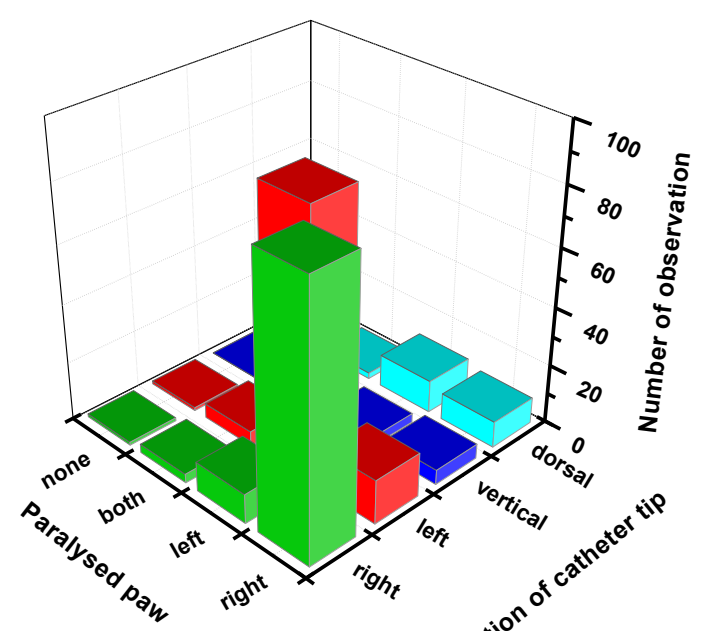

B

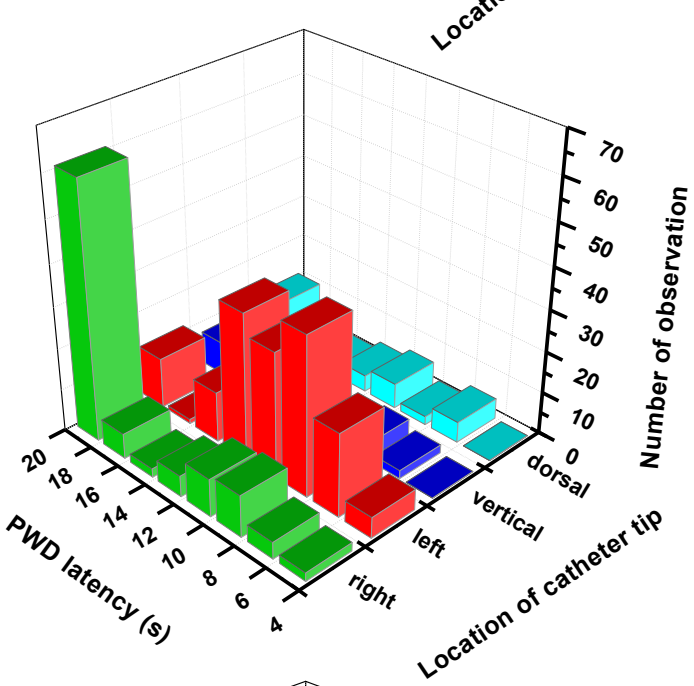

C

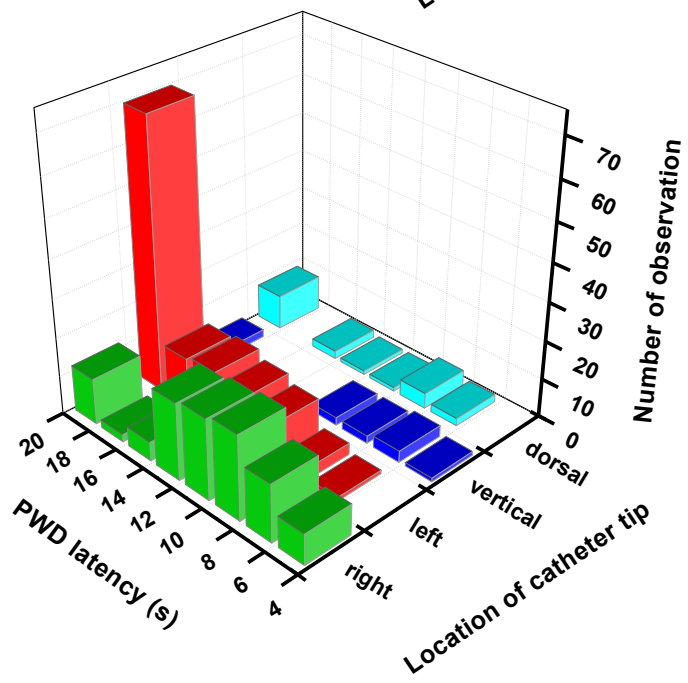

Fig. 11 Three-dimensional bivariate distribution histograms showing the correlation between the side position of the catheter tip and the side of the motor paralysis (A) and the correlation between the side position of the catheter tip and the paw withdrawal (PWD) latency at the right side (B) and left side (C) ( $\mathrm{n}=376)$. 


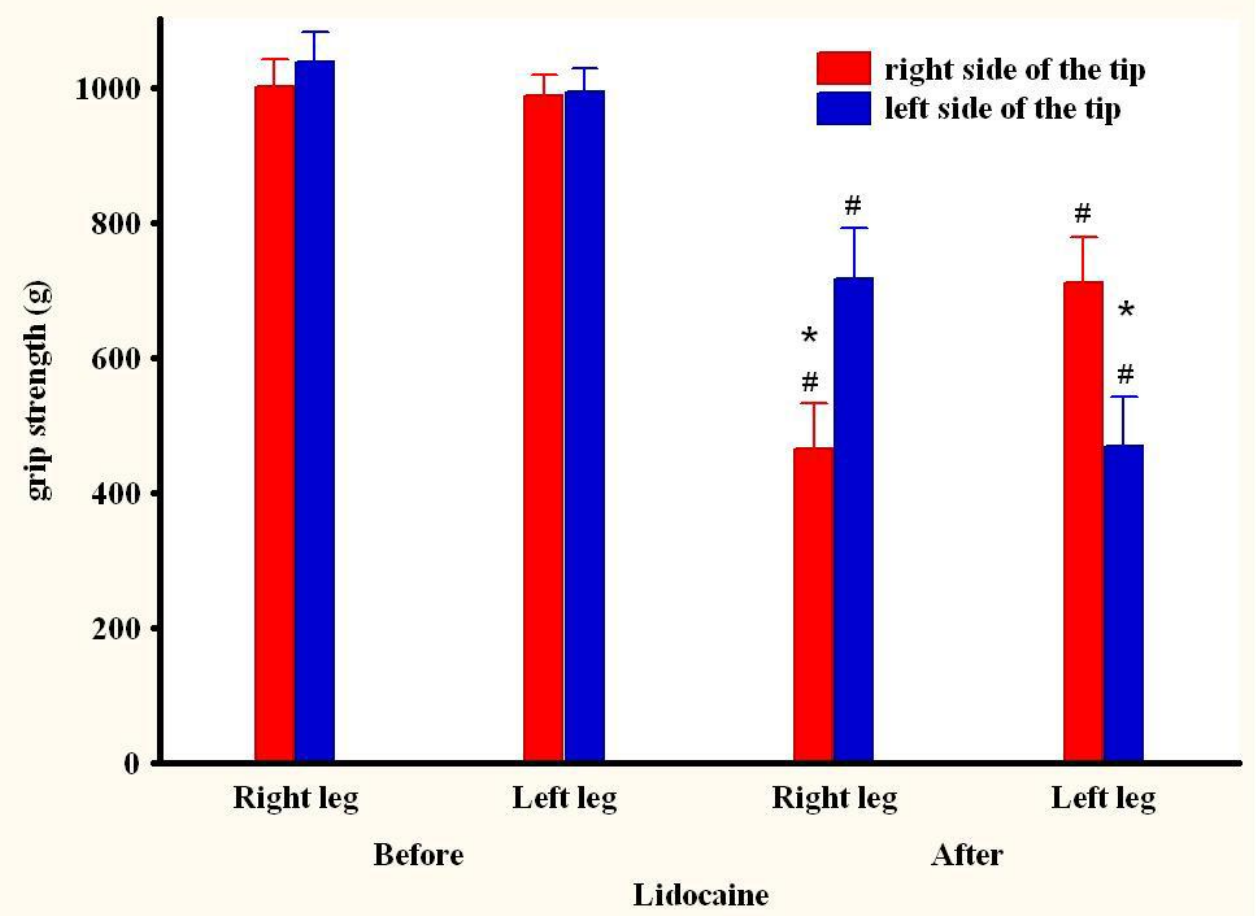

Fig. 12 Grip strength of right and left hind limb before and after $100 \mu \mathrm{g}$ lidocaine administration.* Significantly different from baseline grip strength. \# Significant differences between right and left hind limb depending on the side position of the catheter tip after lidocaine administration $(\mathrm{n}=23)(\mathrm{P}<0.005)$.

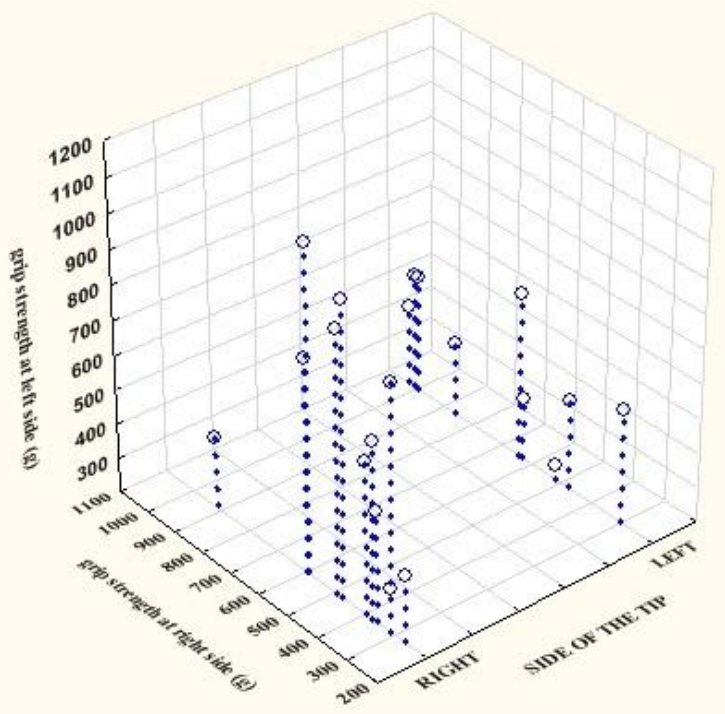

Fig. 13 Three-dimensional bivariate distribution histograms showing the correlation between the side position of the cannula tip and the grip strength at the right side and the left side after $100 \mu \mathrm{g}$ lidocaine administration. 
The baseline grip strength was $1006 \pm 26.5 \mathrm{~g}$ for the right and $968 \pm 23.6 \mathrm{~g}$ for the left hind limb, with no significant differences between the two sides (Fig. 12).

A significant correlation was observed between the side position of the cannula tip and the grip strength after $100 \mu \mathrm{g}$ lidocaine administration $(\mathrm{r}=0.50$ and $\mathrm{r}=0.51$ for the left and the right hind limb, respectively; $\mathrm{P}<0.05$ ) (Fig 13). 


\section{Experiment II}

There were no significant differences in paw withdrawal responses to noxious thermal stimuli between the hind paws before the intraplantar injection of carrageenan. The overall mean paw withdrawal time for the right and left paws were $9.3 \pm 0.26$ and $9.9 \pm 0.25 \mathrm{~s}(\mathrm{n}=72)$, respectively. The carrageenan injection induced an inflammation of the injected hind paw, as evidenced by oedema and erythema. The paw withdrawal latencies of the carrageenaninjected paw were significantly reduced to $3.6 \pm 0.13 \mathrm{~s}(\mathrm{P}<0.001, \mathrm{n}=72)$. Thus, thermal hyperalgesia was consistently produced in rats with carrageenan-induced inflammation.

The effects of ketamine enantiomers injected into the subarachnoid space were evaluated during the peak hyperalgesic response 3-6 $\mathrm{h}$ after carrageenan. Individual ketamine enantiomers, racemic ketamine, and saline had no influence on paw withdrawal latencies of the noninflamed paws (Fig. 14-17).

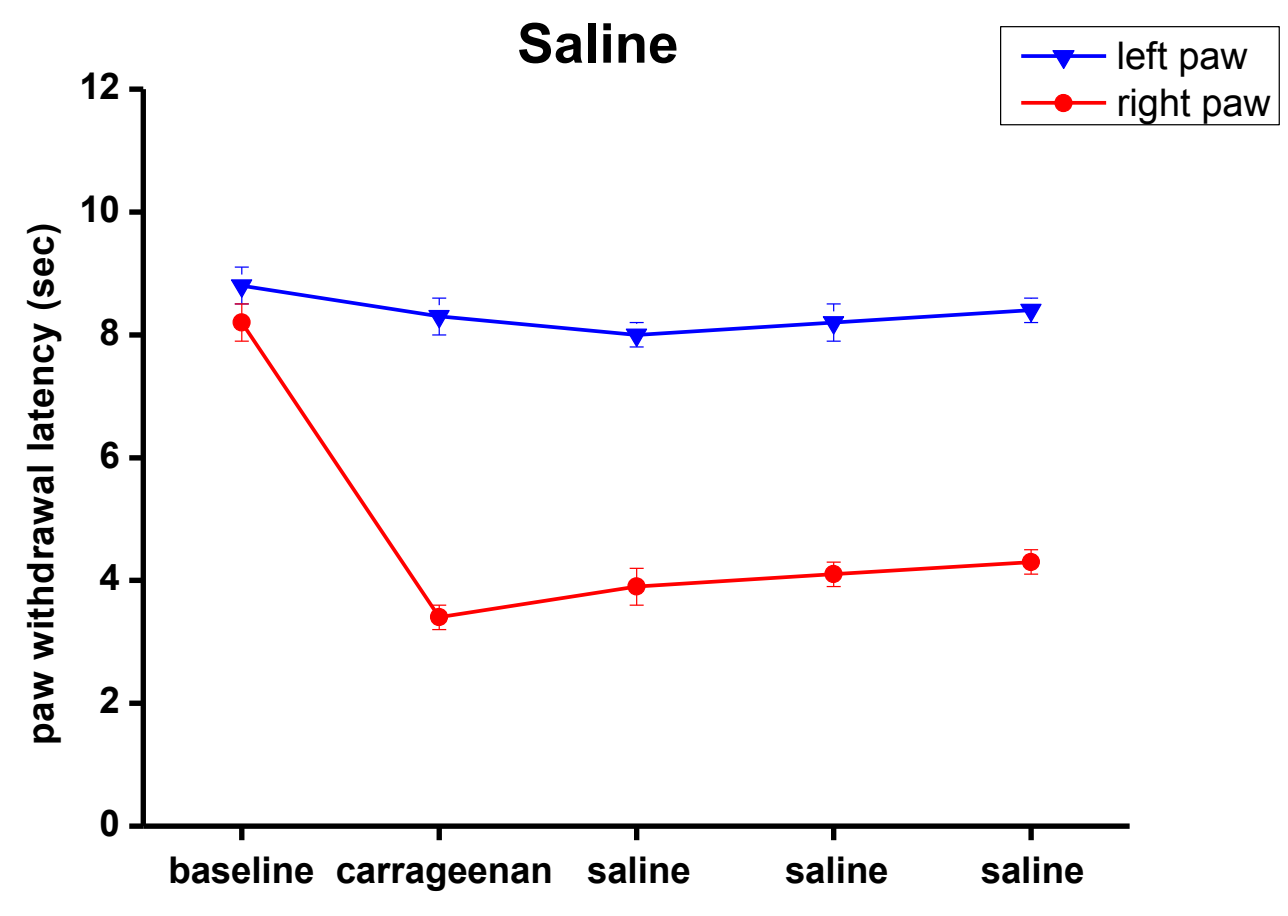

Fig. 14 Effect of saline on paw withdrawal latencies of rats receiving unilateral injection of carrageenan into the right hind paw. Withdrawal latencies from the thermal stimuli of both injected and noninjected paws are plotted against repeated saline administration $(\mathrm{n}=18)$. 
In the injected paws, two-way ANOVA on raw data revealed a significant effect for treatment and dose [F-values [df]: 4.19 [3], 38.9 [3], respectively]. ANOVA for repeated measures showed significant treatment effects for $\mathrm{S}(+)-, \mathrm{R}(-)-$, and racemic ketamine within groups [Fvalues [df]: 12.54 [3], 10.69 [3], 17.67 [3], respectively]. Racemic ketamine had significant effects after the second and third dose (Fig. 15), and S(+)-ketamine had significant effects only at the largest dose compared with saline (Fig. 16). Although indicating a clear trend toward a dose-dependent reversal of thermal hyperalgesia, R(-)- ketamine did not achieve statistical significance compared with saline (Fig. 17).

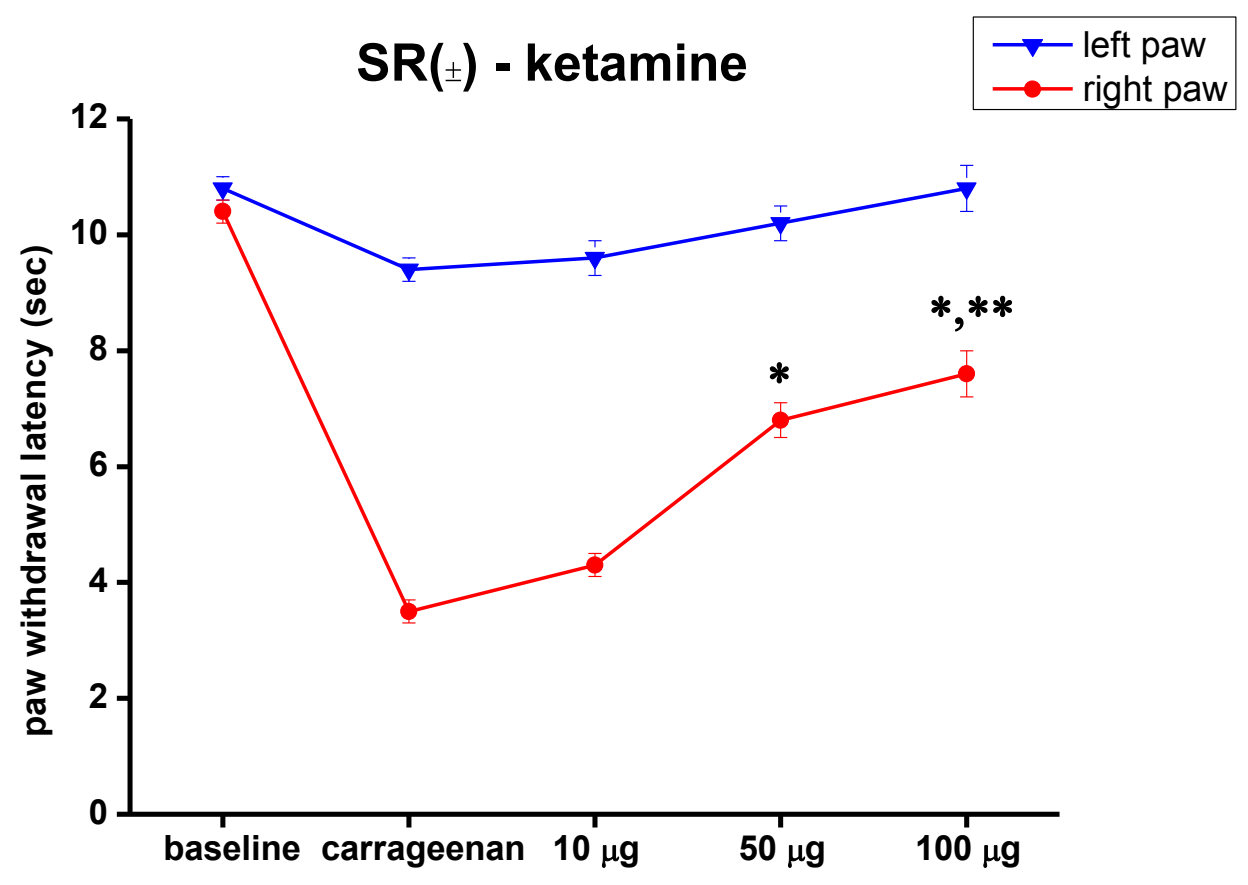

Fig. 15 Effect of racemic ketamine on paw withdrawal latencies of rats receiving unilateral injection of the carrageenan into the right hind paw. Withdrawal latencies from the thermal stimuli of both injected and noninjected paws are plotted against different drug doses. *Significantly different from saline treatment. **Significantly different from $\mathrm{R}(-)$ ketamine treatment $(\mathrm{P}<0.05)(\mathrm{n}=18)$. 


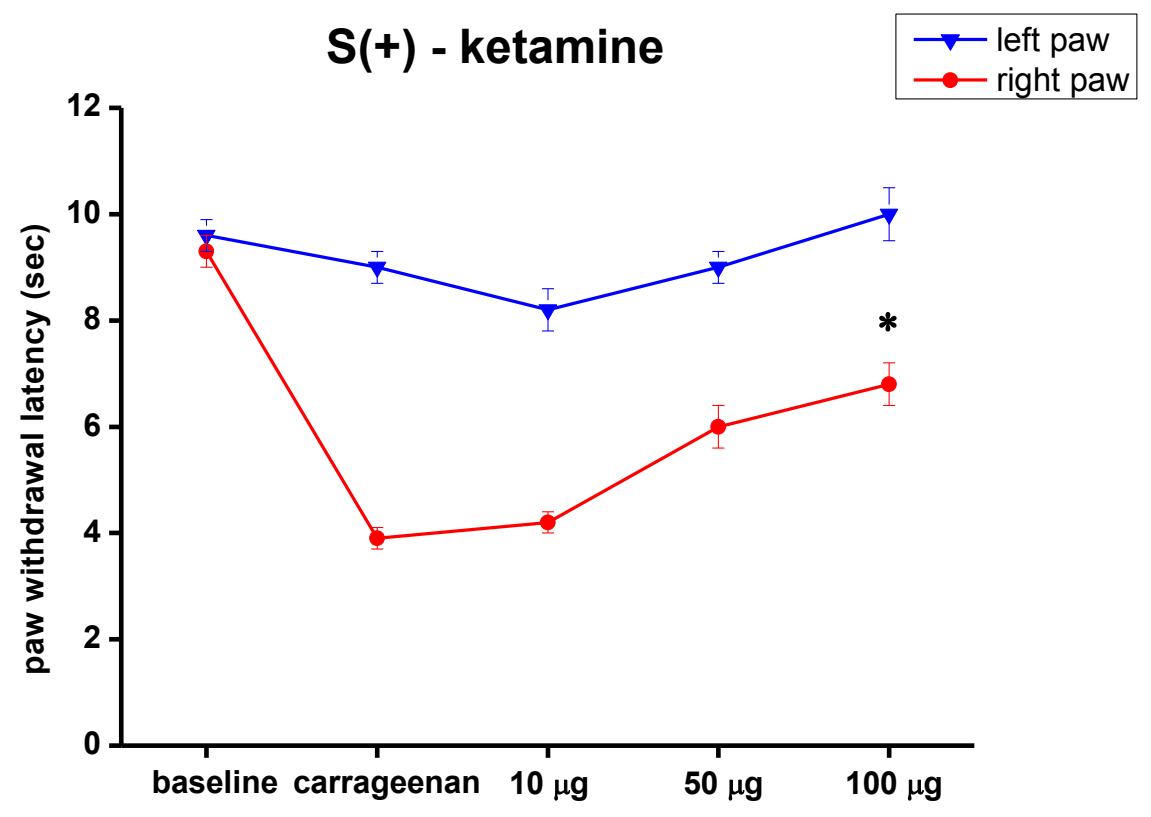

Fig. 16 Effect of $\mathrm{S}(+)$-ketamine isomer on paw withdrawal latencies of rats receiving unilateral injection of the carrageenan into the right hind paw. Withdrawal latencies from the thermal stimuli of both injected and noninjected paws are plotted against different drug doses. $*$ Significantly different from saline treatment $(\mathrm{P}<0.05) .(\mathrm{n}=18)$

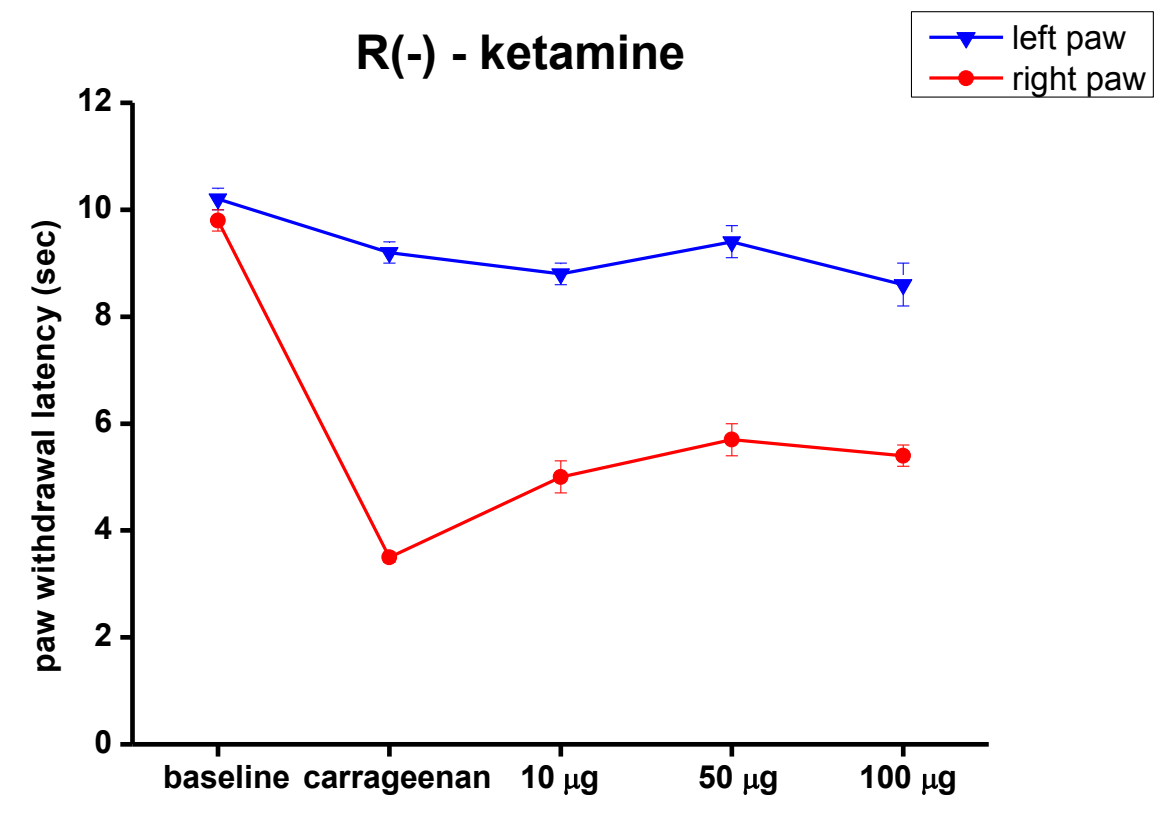

Fig. 17 Effect of R(-)-ketamine isomer on paw withdrawal latencies of rats receiving unilateral injection of the carrageenan into the right hind paw. Withdrawal latencies from the thermal stimuli of both injected and noninjected paws are plotted against different drug doses $(\mathrm{n}=18)$. 
In the hot plate test, the largest dose of both isomers caused a significant increase in licking latency at $10 \mathrm{~min}$ (Fig. 17), although this dose induced supraspinal effects, as well; for example, the animals demonstrated circling movements and head weaving.

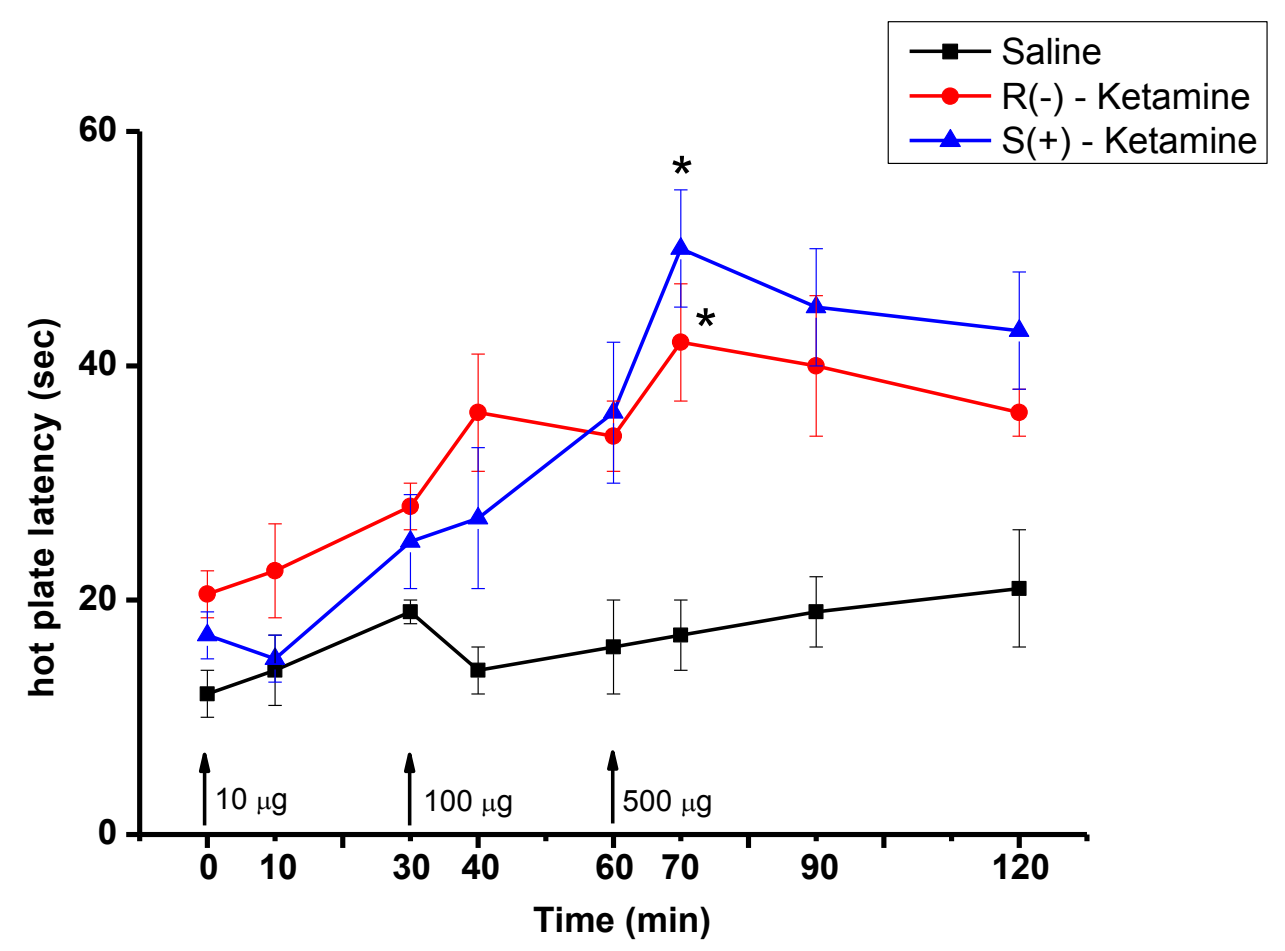

Fig. 18 Effects of ketamine isomers and saline on hot plate latencies. Arrow = drug administration. *Significant different from saline treatment $(\mathrm{P}<0.05)(\mathrm{n}=18)$. 
Neither S(+)- nor R(-)-ketamine significantly influenced the tail flick latency in the applied doses (Fig. 19)

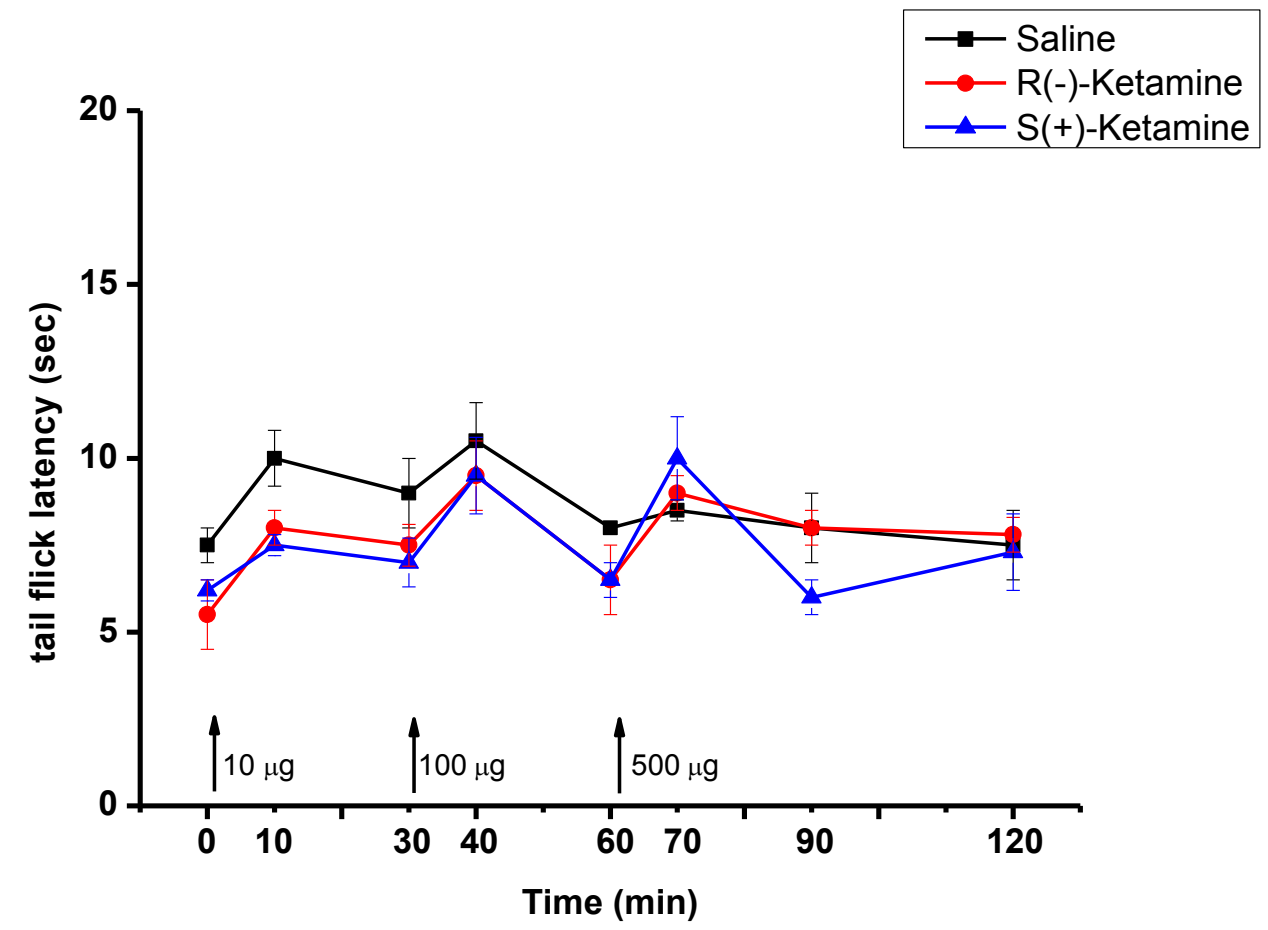

Fig. 19 Effects of ketamine isomers and saline in tail flick latencies. Arrow = drug administration $(\mathrm{n}=18)$. 


\section{DISCUSSION}

\section{Experiment I}

Our results demonstrated that the intrathecal catheter tips were always at appropriate level, corresponding to the spinal segments that innervate the hind paw. The side position of the catheter tips, however, exhibited large variability, and they influenced significantly the anaesthetic effect of the small dose of lidocaine. The anaesthetic potency of lidocaine correlated with the location of the catheter tip.

Yaksh and Rudy introduced Intrathecal catheterization in small animals (104). Concerning the site of action of a drug administered into the spinal subarachnoid space, they suggest that there was clearly an alternative: the effect could be exerted either on the nerve roots or on cell bodies and synapses that lie within the grey matter of the cord. In the latter case, there is a possibility that the ability of the drug to produce an effect is contingent upon its ability to reach the grey matter. Physicochemical properties of the drug injection, such as molecular weight and lipophilicity, should therefore be considered in assessing the efficacy of action of any drug, because these properties are likely to influence the penetration into the spinal cord, the circulation, or both. Yaksh and Rudy performed calibration experiments with bromophenol blue dye, $[3 \mathrm{H}]$ naloxone $\mathrm{HCl}$ and ${ }^{14} \mathrm{C}$-urea in a few animals (104). These data revealed that there was little rostrocaudal diffusion of the injection along the spinal axis and that the spreading depended on the volume applied. The spread of the dye in a volume of $5 \mu \mathrm{l}$ was limited to approximately $0.5-1.5 \mathrm{~cm}$ from the catheter tip. Furthermore, even for compounds such as naloxone, which can permeate neural tissues rapidly, the levels that appear in the brain after spinal subarachnoid administration of the drug were small. In contrast, our earlier results demonstrated that the supraspinal, mydriatic effect of the intrathecally administered lipophilic $\alpha 2$-adrenoceptor agonist, dexmedetomidine, appeared at a smaller dose than that required for its antinociceptive effect (37). Thus, the properties of the drug and the longitudinal position of the catheter tip clearly play major roles in the effect of the compound, whereas few authors have noted that the position of the catheter tip in the transverse plane is also important as concerns successful subarachnoid spread. The volume of the drug and the route of delivery (single injection or microinfusion) also could influence the spread and the effect of the applied drugs $(99,104)$. 
Wiesenfeld-Hallin reported that the location of the catheter tip affected the antinociceptive effect of intrathecal morphine in rats (99). It is very important that she applied a continuous intrathecal infusion in a small dose and volume $(24 \mu \mathrm{g} / \mathrm{h}$ and $0.5 \mu \mathrm{l} / \mathrm{h}$, respectively). In that work, rats with the catheter tip situated on the dorsal lumbar enlargement of the spinal cord displayed a clear antinociceptive effect of morphine in the hot-plate test and in the reduction of autotomy, whereas rats without this placement did not. Furthermore, in 18 of 26 animals, the catheter tip was located away from the dorsum of the spinal cord, which also suggested a large variability in the position. However, the exact locations of the catheter tips were not mentioned. Using autoradiography, Cridland et al. reported that the intrathecal spread of labelled substance $\mathrm{P}$ was dependent on the catheter tip position $(10,17)$. When unilateral anaesthesia was observed after the injection of local anaesthetics, lateral subarachnoid placement of the catheter was subsequently confirmed. The authors suspected that the unilateral uptake of the label simply reflected the position of the catheter tip. Hersh et al. determined the location of the catheter tip within the subarachnoid space in 29 animals (33). They observed that the intensity of the conduction block achieved after chloroprocaine in a large volume $(40 \mu \mathrm{l})$ was dependent on the location of the catheter tip. Akerman investigated motor and sensory anaesthesia after $20 \mu \mathrm{l}$ of $5 \%$ lidocaine (1). Although this dose was 10 times larger than what we applied, they also observed unilateral blockade in 2 of 10 operated rats. Similar to our results, a very fast onset of anaesthesia and short-lasting effects were observed in rats and mice. It was also mentioned that the tip of the catheter was not always located dorsally in the subarachnoid space. Asato et al. reported a study of the distribution of intrathecal catheter tip positions in rats $(n=66)$ (5). Because they used another categorization of the subarachnoid space, our results display several differences from their observations; e.g., in their study the catheter tips were located laterally in $58 \%$ of the cases, whereas the corresponding figure in our study was $79 \%$. Furthermore, Asato et al. found that the longitudinal position of the catheter tip was significantly different in the ventral and dorsal catheter tip groups (5). We did not find such a correlation: in contrast, the longitudinal position of the catheter tip correlated significantly with the weight of the animals. Similar to Asato et al., we found animals without a motor impairment despite that their catheter tip was situated in the spinal cord (5).

There are several methods for determining the effect of a drug on both hind paws after unilateral inflammation or nerve injury. In these cases it cannot be excluded that the effects of 
small doses of such drugs might be influenced by the location of the catheter tip. Because our results revealed that the location of the catheter tip correlated with the anaesthetic potency of small-dose lidocaine, we suggest that studies of the effects of drugs might well be predicted by preliminary determination of the potency of lidocaine on both sides. If the goal of a study is to investigate the effect of a drug on the injured side, then the injury should be performed on the side where lidocaine is more effective.

\section{Experiment II}

The importance of stereochemistry in clinical pharmacology and therapeutics has been widely recognized in the last decade, particularly in the arena of new drug development (10) . Most drugs are optically active and are used clinically as the racemate (an equal mixture of optical isomers). Approximately $60 \%$ of anaesthetics are chiral drugs; some of them are administered as individual enantiomers (for an excellent review, see Reference (10)). Although the R- and S-isomers contain the same substituent groups, they occupy different positions in space. Consequently, the R- and S-enantiomers may form different threedimensional relationships in the asymmetric environment of receptors and there may be significant differences in their pharmacodynamic and pharmacokinetic properties, i.e., individual enantiomers may differ in their receptor effects, dispositions, and toxicity.

Originally, Marietta et al. reported differences in pharmacological potencies of the optical isomers of ketamine in rats after intravenous injection (59). The (+)-enantiomer had a higher therapeutic index than the racemate or the (-)-enantiomer, and at equihypnotic doses, the (+)isomer caused less locomotor stimulation than the (-)-isomer. Ryder et al. showed that the (+)isomer was 3 times more potent than the (-)-isomer as an analgesic in the phenylquinone writhing test in mice (88). Stereoselective differences in ketamine affinity for NMDA receptors, and ketamine effects on NMDA receptor ion-current, catecholamine reuptake, and acetylcholinesterase activity have also been observed (48) .

However, some effects of ketamine are non-stereospecific. Hirota et al. found that the two ketamine isomers produced equipotent spasmolytic effects on airway smooth muscle precontracted with histamine, but they differed in their ability to potentiate the relaxing effect of adrenaline, with $\mathrm{S}(+)$-ketamine producing the greater potentiation (35). Furthermore, the optical isomers of ketamine had equipotent cardiodepressant effects in the guinea pig (89). 
In human studies, White et al. reported differences in their anaesthetic potency, intraoperative effects, postoperative analgesia, and side effects (97). The $\mathrm{S}(+)$-enantiomer has 4 times the potency of the R(-)- enantiomer of ketamine and may have significant clinical advantages in comparison with the racemic drug. Furthermore, $S(+)$-ketamine possesses superior efficacy with fewer side effects compared with the racemate. There are also differences in the pharmacokinetics of the ketamine enantiomers. Administered individually, the plasma clearance of $\mathrm{S}(+)$-ketamine is greater than that of the $\mathrm{R}(-)$-enantiomer. Kharasch and Labroo have demonstrated a relative enantiomeric selectivity in the human metabolism (47).

A series of clinical studies has suggested potent analgesia after epidural or spinal administration of racemic ketamine (82). Ketamine has been administered epidural to humans for pain relief without the side effects, such as respiratory depression, urinary retention, or pruritus, frequently observed after epidural opioids (81). The neuraxial use of ketamine raised questions about potential toxicity (58), although in clinical studies, neurologic lesions were not reported after the intrathecal administration of ketamine (81). Preservatives (benzethonium chloride or chlorobutanol) used in ketamine solution in some cases were thought to cause neurological damage in animals (9). The isomers of ketamine do not induce spinal cord lesions themselves, but the preservative chlorobutanol led to significant spinal cord damage in rabbits (58). For the possible future clinical use of $\mathrm{S}(+)$-ketamine, it is important that it be produced as a preservative-free solution (See Ketanest-S , Pfizer).

Our results are consistent with the observation that the NMDA receptor antagonists have a particular role in mediating persistent pain and hyperalgesia $(15,16,20,83)$. In behavioural tests, NMDA receptor antagonists attenuate or reverse the thermal hyperalgesia evoked by local inflammation or peripheral neuropathy, without any analgesic effect on the response to noxious stimulation of the contralateral, non-affected limb $(83,106)$. Furthermore, when tested in rats without nerve injury or tissue damage, NMDA receptor antagonists usually do not produce significant behavioural analgesia until the doses used result in visible motor dysfunction $(20,103,106)$. However, in contrast to results from systemic administration in humans superior efficacy was observed in racemic ketamine, rather than in $S(+)$-ketamine (97). This finding can hardly be interpreted based on our study. The neurochemical mechanism of ketamine-induced depression of spinal nociceptive neurons in the spinal cord is not clear. It interacts with not only NMDA receptors, but also with opioid, monoaminergic, and muscarinic receptors and voltage-sensitive calcium channels $(34,90)$. In addition, it has 
been shown that in the spinal cord, acute NMDA produced thermal hyperalgesia is mediated by activation of the constitutive neuronal form of nitric oxide synthase and the production of nitric oxide $(53,65)$. Therefore, several neuronal receptor systems may be involved in the depressant action of ketamine on the excitation of WDR neurons in the DH of the spinal cord. The antinociceptive effects of subanaesthetic doses of ketamine are likely to occur at concentrations sufficient to block the NMDA channels. At larger (anaesthetic) doses, other receptors, in particular opioid $\delta$-receptors and $\mu$-receptor sites, may contribute to the pharmacological effects of ketamine (90). Joo et al. investigated the interaction of intrathecal ketamine and its enantiomers with morphine and the $\alpha_{2}$-adrenoceptor agonist, dexmedetomidine, in the TF test (43). They observed synergistic interactions between the higher dose $(100 \mu \mathrm{g})$ of racemic ketamine or $\mathrm{S}(+)$-ketamine and morphine $(3 \mu \mathrm{g})$ or dexmedetomidine in rats and this potentiation was independent of the anaesthetic drug applied. Coadministration of a low dose of morphine $(0.3 \mu \mathrm{g})$ or dexmedetomidine with $\mathrm{S}(+)$ ketamine $(100 \mu \mathrm{g})$, which in itself induced no changes in pain sensation or behaviour, caused a significant long-lasting antinociception, without any side-effects. 


\section{SUMMARY}

\section{Experiment I}

Many previous studies suggest that the correct location of the catheter tip is crucial concerning the effect obtained. However, the previous studies did not suggest a reliable method for the prediction of the location of the catheter tip before experiments on living animals.

We revealed that:

1. the tips of chronic intrathecal catheters were found to be variously located in the transverse plane in the rat spinal subarachnoid space.

2. the position of the intrathecal catheter tip influences the pharmacological effects of the local anaesthetic lidocaine.

3. the paralytic and/or antinociceptive effect of a small dose of lidocaine before the experiments is a simple and reliable method for prediction of the side position of the catheter tip before rats are used in further studies of spinal systems that mediate nociception and antinociception.

4. the differences between the effects of the drug on the two sides might be very important, especially if small doses of the drug are applied and their effects are investigated on both sides. 


\section{Experiment II}

This was the first study to examine the antinociceptive efficacy of the optical isomers of ketamine after intrathecal administration.

We demonstrated that:

1. Both racemic and $S(+)$-ketamine increased significantly paw withdrawal latencies in the inflamed paw.

2. The $\mathrm{R}(-)$-ketamine was ineffective to reducing thermal hyperalgesia.

3. Conversely, acute pain tests did not reveal any differences between ketamine enantiomers; i.e. only the largest dose $(500 \mu \mathrm{g})$ caused a non-stereospecific, significant increase in hot plate latency, but this dose caused supraspinal effects as well. Neither $\mathrm{S}(+)$-nor R(-)ketamine did not show any significant effect in tail flick test in applied doses.

Our result suggest that, the potential advantages of using pure enantiomers rather than a racemate include a less complex and more selective pharmacodynamic profile, a higher therapeutic index, less complex pharmacokinetics, less complex drug interactions, and less complex concentration-response relationships. 


\section{AKNOWLEDGEMENTS}

First and foremost I would like to express my gratitude to Dr. Margit Szikszay and Prof. Dr. György Benedek who made it possible for me to work at the Department of Physiology.

I owe sincere thankfulness to my supervisor Prof. Dr. Gyöngyi Horváth who introduced me to the world of scientific work and taught me several scientific techniques. I had the chance to learn from her how to design and carry out a successful experiment and publish its results. I would also like to thank her for her continuous support both in my professional and private life.

I wish to thank Prof. Dr. Gábor Jancsó for providing me the possibility to join the 'Neurosciences' $\mathrm{PhD}$ program.

I would like to show my gratitude for the help I received from Dr. Gabriella Kékesi and Dr. Gabriella Joó in executing the experiments and for them just always being there when I was in need.

I also wish to thank my colleagues Dr. Éva Deák and Orsolya Oszlács for their support and encouragement.

I am grateful to Anikó Jász who helped me find the way in the maze of bureaucracy. Her absolute faith in my abilities and her friendship gave me strength during writing the thesis.

I would also like to thank the employees of the Department of Physiology for all of their help that contributed to my success.

I am particularly grateful and indebted to my family: my husband, my daughters and my parents for their continuous support, encouragement and understanding throughout my work. 


\section{REFERENCE LIST}

1. Akerman S.B.A. A methodological study of spinal (subarachnoid) anaesthesia in the rat and the mouse. Br.J.Anaesth. 57: 329-332, 1985.

2. Almeida T.F., Roizenblatt S., Tufik S. Afferent pain pathways: a neuroanatomical review. Brain Res. 1000: 40-56, 2004.

3. Amico-Ruvio S.A., Murthy S.E., Smith T.P., Popescu G.K. Zinc effects on NMDA receptor gating kinetics. Biophys.J. 100: 1910-1918, 2011.

4. Anders D.L., Blevins T., Smothers C.T., Woodward J.J. Reduced ethanol ingibition of $N$-methyl- $D$-aspartate receptors by deletion of NR1 C0 domain or everexpression of alpha-acinin-2 proteins. J.Biol.Chem. 275: 15019-15024, 2000.

5. Asato F., Butler M., Blomberg H., Gordh T. Distribution of intrathecal catheter positions in rat. Acta Anaesthesiol.Scand. 45: 608-611, 2001.

6. Basbaum A.I., Bautista D.M., Scherrer G., Julius D. Cellular and molecular mechanisms of pain. Cell 139: 267-284, 2009.

7. Bass N.H.,Lundborg P. Postnatal development of bulk flow in the cerebrospinal fluid system of the albino rat: clearance of carboxyl- $\left[{ }^{14} \mathrm{C}\right]$ inulin after intrathecal infusion. Brain Res. 52: 323-332, 1973.

8. Bleakman D., Alt A., Nisenbaum E.S. Glutamate receptors and pain. Seminars in Cell Develop.Biol. 17: 592-604, 2006.

9. Brock Utne J.G., Mankowitz E., Kailichurum S., Downing J.W. Effects of intrathecal saline and ketamine with and without preservative on the spinal nerve roots of monkeys. S.Afr.Med.J. 61: 360-361, 1982.

10. Calvey T.N. Isomerism and anaesthetic drugs. Acta Anaesthesiol.Scand. 106 (Suppl): 83-90, 1995.

11. Caspary T.,Anderson K.V. Patterning cell types in the dorsal spinal cord what the mouse mutants say. Nat.Rev.Neurosci. 4: 289-297, 2003.

12. Caterina M.J., Gold M.S.,Meyer R.A. Molecular biology of nociceptors. In: Hunt S.P.,Koltzenburg M. (eds) The neurobiology of pain (Molecular and cellular neurobiology). Oxford University Press, Oxford, 1-27, 2005.

13. Chen H.S.,Lipton S.A. Mechanism of memeantine block of NMDA-activated channels in rat retinal ganglion cells: unceompetitive antagonism. J.Physiol. 499: 24-46, 2013.

14. Christensen M.D., Everhart A.W., Pickelman J.T., Hulsebosch C.E. Mechanical and thermal allodynia in chronic central pain following spinal cord injury. Pain 68: 97-107, 1996. 
15. Coderre T.J.,Melzack R. Central neural mediators of secondary hyperalgesia following heat injury in rats: neuropeptides and excitatory amino acids. Neurosci.Lett. 131: 71-75, 1991.

16. Coderre T.J.,Van Empel I. The utility of excitatory amino acid (EAA) antagonists as analgesic agents. I. Comparison of the antinociceptive activity of various classes of EAA antagonists in mechanical, thermal and chemical nociceotive tests. Pain 59: 345352, 1994.

17. Cridland R.A., Yashpal K., Romita V.V., Gauthier S., Henry J.L. Distribution of label after intrathecal administration of ${ }^{125}$ I-substance P in the rat. Peptides 8: 213-221, 1986.

18. Davson H.,Segal M.B. Effect of cerebrospinal fluid on volume of distribution of extracellular markers. Brain 92: 131-136, 1969.

19. Davson H., Welch K.,Segal M.B. The secretion of the cerebrospinal fluid. In: (eds) Anonymous physiology and pathophysiology of the cerebrospinal fluid. Churchill Livingstone, London, 189-245, 1987.

20. Dickenson A.H. Spinal cord pharmacology of pain. Br.J.Anaesth. 75: 193-200, 1995.

21. Dingledine R., Borges K., Bowie D., Traynelis S.F. The glutamate receptor ion channels. Pharmacol.Rev. 51: 7-60, 1999.

22. Dirajlal S., Pauers L.E., Stucky C.L. Differential response properties of IB4-positive and -negative unmyelinated sensory neurons to protons and capsaicin. J.Neurophysiol. 89: 513-524, 2003.

23. Dougherty P.M.,Staats P.S. Intrathecal drug therapy for chronic pain. Anesthesiology 91: 1891-1918, 1999.

24. Eby G.A.,Eby K.L. Rapid recovery from major depression using magnesium treatment. Med.Hypot. 67: 362-370, 2006.

25. Ehlers M.D., Zhang S., Bernhardt J.P., Huganir R.L. Inactivation of NMDA receptors by direct interaction of calmodulin with the NR1 subunit. Cell 84: 745-755, 1996.

26. Fagg G.E. Phencyclidine and related drugs bind to the activated $N$-methyl- $D$-aspartate receptor-channel complex in rat brain membranes. Neurosci.Lett. 76: 221-227, 1987.

27. Fürst Z. Transmitters involved in antinociception in the spinal cord. Brain Res.Bull. 48: 129-141, 1999.

28. Grant G.J., Vermeulen K., Zakowski M.I., Sutin K.M., Ramanathan S., Langerman L., Weissman T.E., Turndorf H. A rat sciatic nerve model for independent assessment of sensory and motor block induced by local anesthetics. Anesth.Analg. 75: 889-894, 1992.

29. Hargreaves K., Dubner R., Brown F., Flores C., Joris J. A new and sensitive method for measuring thermal nociception in cutaneous hyperalgesia. Pain 32: 77-88, 1988. 
30. Harman R.J.,Shaw G.G. The spontaneous and evoked release of spermine from rat brain in vitro. Br.J.Pharmacol. 73: 165-174, 2011.

31. Hebel R.,Stromberg M.W. Anatomy and embriology of the laboratory rat. BioMed Verlag, Wörthsee, 1986.

32. Herin G.A.,Aizenman E. Amino terminal domain regulation of NMDA receptor function. Eur.J.Pharmacol. 500: 101-111, 2004.

33. Hersh E.V., Condouris G.A., Havelin D. Actions of intrathecal chloroprocaine and sodium bisulfite on rat spinal reflex function utilizing a noninvasive technique. Pain 72 : 1077-1082, 1990.

34. Hirota K.,Lambert D.G. Ketamine: its mechanism(s) of action and unusual clinical uses. Br.J.Anaesth. 77: 441-444, 1996.

35. Hirota K., Sato T., Rabito D.F. Rleaxant effect of ketamine and its isomers on histamine-induced contraction of tracheal smooth muscle. Br.J.Anaesth. 76: 266-270, 1996.

36. Hoffman P.L., Rabe C.S., Grandt K.A., Valverius P., Hudspith M., Tabakoff B. Ethanol and the NMDA receptor. Alcohol 7: 229-231, 1990.

37. Horvath G., Kovacs M., Szikszay M., Benedek G. Mydriatic and antinociceptive effects of intrathecal dexmedetomidine in conscious rats. Eur.J.Pharmacol. 253: 61-66, 1994.

38. Horváth Z.C., Czopf J., Buzsáki G. MK-801-induced neuronal damage in rats. Brain Res. 753: 181-195, 1997.

39. Hudspith M.J. Glutamate: a role in normal brain function, anaesthesia, analgesia and CNS injury. Br.J.Anaesth. 78: 731-747, 1997.

40. Huggins D.J.,Grant G.H. The function of the amino terminal domain in NMDA receptor modulation. J.Mol.Graph.Model. 23: 381-388, 2005.

41. Janssen P.A.J., Niemegeers C.E., Dony J.C.G. The inhibitory effect of fentanyl and other morphine-like analgesics on the warm water induced tail withdrawal reflex in rats. Arzneim.Forsch.Drug Res. 13: 502-507, 1963.

42. Joo G.,Horvath G. A ketamin és izomerjeinek szerepe a fájdalomcsillapításban. Aneszteziol.Int.Ter. 31: 9-20, 2001.

43. Joo G., Horvath G., Klimscha W., Kekesi G., Dobos I., Szikszay M., Benedek G. Tthe effects of ketamine and its enentioners on the morphine- or dexmedetomidine-induced antinociception after intrathecal administation in rats. Anesthesiology 93: 231-241, 2000 .

44. Julius D.,Basbaum A.I. Molecular mechanisms of nociception. Nature 413: 203-210, 2001. 
45. Kahle W.,Frotscher M. Nervous system and sensory organs. Thieme, Stuttgart, New York, 2003.

46. Kandel E.R., Schwartz J.H., Jessell T.M. Principle of neural science. McGrow-Hill, New York, 2000.

47. Kharasch E.D.,Labroo R. Metabolism of ketamine stereoisomers by human liver microsomes. Anesthesiology 77: 1201-1207, 1992.

48. Klepstad P., Maurset A., Moberg E.R., Oye I. Evidence of a role for NMDA receptors in pain perception. Eur.J.Pharmacol. 187: 513-518, 1990.

49. Kohrs R.,Durieux M.E. Ketamine: Teaching an old drug new tricks. Anesth.Analg. 87: 1186-1193, 1998.

50. Kovacic P.,Somanathan R. Clinical physiology and mechanism of dizocilpine (MK801). Electron transfer, radicals, redox metabolites and bioactivity. Oxidat.Med.Cell.Longevit. 3: 13-22, 2010.

51. Kutzing M.K., Luo V., Firestein B.L. Protection from glutamate-induced excitotoxicity by memantine. Annals Biomed.Engin. 40: 1170-1181, 2012.

52. Lei S.Z., Pan Z.H., Aggarwal S.K., Chen H.-S.V., Hartman J., Sucher N.J., Lipton S.A. Effect of nitric oxide production on the redox modulatory site on the NMDA receptorchannel complex. Neuron 8: 1087-1099, 1992.

53. Li P., Tong C., Eisenach J.C., Figueroa J.P. NMDA causes release of nitric oxide from rat spinal cord in vitro. Brain Res. 637: 287-291, 1994.

54. Lim H.S., Kim J.-M., Choi J.-G., Ko Y.K., Shin Y.S., Jeon B.H., Park J.B., Lee J.-H., Kim H.-W. Intrathecal ketamine and pregabalin at sub-effective doses synergistically reduces neuropathic pain without motor dysfunction in mice. Biol.Pharm.Bull. 36: 125130, 2013.

55. Lipton S.A. NMDA receptors, glial cells, and clinical medicine. Neuron 50: 9-11, 2006.

56. Lugo-Huitrón R., Muniz P.U., Pineda B., Bedraza-Chaverrí J., Ríos C., Pérez-de la Cruz V. Quinolinic acid: an endogenous neurotoxin with multiple targets. Oxidat.Med.Cell.Longevit. 2013: 1-14, 2013.

57. Lutfy K., Cai S.X., Woodward R.M., Weber E. Antinociceptive effects of NMDA and non-NMDA receptor antagonists in the tail flick test in mice. Pain 70: 31-40, 1997.

58. Malinovsky J.M., Lepage J.Y., Cozian A., Mussini J.M., Pinaudt M., Souron R. Is ketamine or its preservative responsible for neurotoxicity in the rabbit? Anesthesiology 78: 109-115, 1993.

59. Marietta M.P., Way W.L., Castagnoli N.Jr., Trevor A.J. On the pharmacology of the ketamine enantiomorhs in the rat. J.Pharmacol.Exp.Ther. 202: 157-165, 1977. 
60. Martin D., Morrisett R.A., Bian X.P., Wilson W.A., Swartzwelder H.S. Ethanol inhibition of NMDA mediated depolarizations is increased in the presence of $\mathrm{Mg}^{2+}$. Brain Res. 546: 227-234, 1991.

61. McCleskey E.W.,Gold M.S. Ion channels of nociception. Ann.Rev.Physiol. 61: 835856, 1999.

62. McMahon S.B.,Priestley J.V. Nociceptor plasticity. In: Hunt S.P.,Koltzenburg M. (eds) The neurobiology of pain (Molecular and cellular neurobiology). Oxford University Press, oxford, 35-64, 2005.

63. Medina I., Filippova N., Bakhramov A., Bregestovski P. Calcium-induced inactivation of NMDA receptor-channels evolves independentrly of run-down in cultured rat brain neurones. J.Physiol. 495: 411-427, 1996.

64. Mei X., Wang W., Wang W., Li Y., Zhang H., Wu S., Li Y., Xu L. Inhibiting astrocytic activation: a novel analgesic mechanism of ketamine at the spinal level? J.Neurochem. 109: 1691-1700, 2009.

65. Meller S.T., Dykstra C., Gebhart G.F. Acute thermal hyperalgesia in the rat is produced by activation of $\mathrm{N}$-methyl-D-aspartate receptors and protein kinase $\mathrm{C}$ and production of nitric oxide. Neuroscience 71: 327-335, 1996.

66. Melzack R.,Wall P.D. Pain mechanisms: a new theory. Science 150: 971-979, 1965.

67. Molander C., Xu Q., Grant G. The cytoarchitectonic organization of the sponal cord in the rat. I. The lower thoracic and lumbosacral cord. J.Comp.Neurol. 230: 133-141, 1984.

68. Möykkynen T.,Korpi E.R. Acute effects of ethanol on glutamate receptors . Basic Clin.Pharmacol.Toxicol. 111: 4-13, 2012.

69. Nakanishi S. Molecular diversity of glutamate receptors and implications for brain function. Science 258: 597-603, 1992.

70. Pai A.,Heining M. Ketamine. Continuing Edu.Anaesth.Crit.Care Pain 7: 59-63, 2007.

71. Paoletti P.,Neyton J. NMDA receptor subunits: function and pharmacology. Curr.Opin.Pharmacol. 7: 39-47, 2007.

72. Pardridge W.M. Drug transport in brain via the cerebrospinal fluid. Fluids and Barriers of the CNS 8: 7-10, 2011.

73. Pérez-Pinzón M.A.,Steinberg G.K. CGS 19755 (Selfotel): a novel neuroprotective agent against CNS injury. CNS Drug Rev. 2: 257-268, 1996.

74. Perkins M.N.,Stone T.W. An iontophoretic investigation of the actions of convulsant kynurenines and their interaction with the endogenous excitant quinolinic acid. Brain Res. 247: 184-187, 1982. 
75. Peter-Szabo M., Kekesi G., Nagy E., Sziver E., Benedek G., Horvath G. Quantitative characterization of a repeated acute joint inflammation model in rats. Clin.Exp Pharmacol Physiol 34: 520-526, 2007.

76. Prado de Carvalho L., Bochet P., Rossier J. The endogenous agonist quinolinic acid and the non endogenous homoquinolinic acid discriminate between NMDAR2 receptor subunits. Neurochem.Internat. 28: 445-452, 1996.

77. Purves D., Augustine G.J., Fitzpatrick D., Hall W.C., LaMantia A.-S., McNamara J.O., Williams S.M. Neuroscience. Sinauer Associates Inc., Sunderland, Massachusetts, USA, 2004.

78. Purves D., Augustine G.J., Fitzpatrick D., Hall W.C., LaMantina A.-S.,McNamara J.O. Pain. In: Purves D., Augustine G.J., Fitzpatrick D., Hall W.C., LaMantia A.-S., McNamara J.O.,Williams S.M. (eds) Neuroscience. Sinauer Assoc.Inc., Sunderland, 209-228, 2004.

79. Quian J., Brown S.D., Carlton S.M. Systemic ketamine attenuates nociceptive behaviors in a rat midel of peripheral neuropathy. Brain Res. 715: 51-62, 1996.

80. Ransom R.W.,Stec N.L. Cooperative modulation of [3H]MK-801 binding to the Nmethyl-D-aspartate receptor-ion channel complex by L-glutamate, glycine, and polyamines. J.Neurochem. 51: 830-836, 1988.

81. Ravat F., Dorne R., Baechle J.P., Beaulaton A., Lenoir B., Palmier B. Epidural ketamine or morphine for postoperative analgesia. Anesthesiology 66: 819-822, 1987.

82. Reich D.L.,Silvay G. Ketamine: an update on the first twenty-five years of clinical experience. Can.J.Anaesth. 36: 186-197, 1989.

83. Ren K., Williams G.M., Hylden J.L., Ruda M.A., Dubner R. The intrathecal administration of excitatory amino acid receptor antagonists selectively attenuated carrageenan-induced behavioral hyperalgesia in rats. Eur.J.Pharmacol. 219: 235-243, 1992.

84. Ririe D.G., Vernon T.L., Tobin J.R., Eisenach J.C. Age-dependent responses to thermal hyperalgesia and mechanical allodynia in a rat model of acute postoperative pain. Anesthesiology 99: 443-448, 2003.

85. Rock D.M.,Macdonald R.L. Spermine and related polyamines produce a voltagedependent reduction of N-methyl-D-aspartate receptor single-channel conductance. Mol.Pharmacol. 42: 157-164, 1992.

86. Rock D.M.,Macdonald R.L. The polyamine spermine has multiple actions on N-methylD-aspartate receptor single-jchannel currents in cultured cortical neurons. Mol.Pharmacol. 41: 83-86, 1992.

87. Rosenthal S.M.,Westbrook G.L. Calcium-induced actin depolymerization reduces NMDA channel activity. Neuron 10: 805-814, 1993. 
88. Ryder S., Way W.L., Trevor A.J. Comparative pharmacology od the optical isomers of ketamine in mice. Eur.J.Pharmacol. 49: 15-23, 1978.

89. Sekino N., Endou M., Hajiri E., Okumura F. Nonstereospecific actions of ketamine isomers on the force of contraction, spontaneous beating rate, and $\mathrm{Ca}^{2+}$ current in the guinea pig heart. Anesth.Analg. 83: 75-80, 1996.

90. Smith D.J., Bouchal R.L., deSanctis C.A., Monroe P.J., Amedro J.B., Perrotti J.M., Crisp T. Properties of the interaction between ketamine and opiate binding sites in vivo and in vitro. Neuropharmacology 26: 1253-1260, 1987.

91. Sternbach R.A. The need for an animal model of chronic pain. Pain 2: 2-4, 1976.

92. Stone T.W.,Addae J.I. The pharmacological manipulation of glutamate receptors and neuroprotection. Eur.J.Pharmacol. 447: 285-296, 2002.

93. Szakács R., Janka Z., Kálmán J. The "Blue" side of glutamatergic neurotransmission: NMDA receptor antagonists as possible novel therapeutics for major depression. Neuropsychoharmacol.Hung. XIV: 29-40, 2012.

94. Todd A.J.,Ribeiro-da-Silva A. Molecular architecture of the dorsal horn. In: Hunt S.P.,Koltzenburg M. (eds) The neurobiology of pain (Molecular and cellular neurobiology). Oxford University Press, Oxford, 65-94, 2005.

95. Traynelis S.F., Wollmuth L.P., McBain C.J., Menniti F.S., Vance K.M., Ogden K.K., Hansen K.B., Yuan H., Myers S.J., Dingledine R. Glutamate receptor ion channels: structure, regulation, and function. Pharmacol.Rev. 62: 405-496, 2010.

96. Wall P.D.,Melzack R. Textbook of pain. Churchill Livingstone, London, 1984.

97. White P.F., Schüttler J., Shafer A., Stanski D.R., Horai Y., Trevor A.J. Comparative pharmacology of the ketamine isomers: studies in volunteers. Br.J.Anaesth. 57: 197203, 1985.

98. White P.F., Way W.L., Trevor A.J. Ketamine-its pharmacology and therapeutic uses. Anesthesiology 56: 119-136, 1982.

99. Wiessenfeld-Hallin Z. The effects of intrathecal morphine and naltrexone on autotomy in sciatic nerve sectioned rats. Pain 18: 267-278, 1984.

100. Williams K. Interactions of polyamines with ion channels. Biochem.J. 325: 289-297, 1997.

101. Wood J.N.,Docherty R. Chemical activators of sensory neurons. Ann.Rev.Physiol. 59: 457-482, 1997.

102. Wuarin-Bierman L., Zahnd G.R., Kaufmann F., Burcklen L., Adler J. Hyperalgesia in spontaneous and experimental animal models of diabetic neuropathy. Diabetologia 30: 653-658, 1987. 
103. Yaksh T.L. Behavioral and autonomic correlates of the tactile evoked allodynia produced by spinal glycine inhibition: effects of modulatory receptor systems and excitatory amino acid antagonists. Pain 37: 111-123, 1989.

104. Yaksh T.L.,Rudy T.A. Chronic catheterization of the spinal subarachnoud space. Physiol.Behav. 17: 1031-1036, 1976.

105. Yamakura T.,Shimoji K. Subunit- and site-specific pharmacology of the NMDA receptor channel. Prog.Neurobiol. 59: 279-298, 1999.

106. Yamamoto T.,Yaksh T.L. Spinal pharmacology of thermal hyperesthesia induced by constriction of sciatic nerve. Excitatory amino acid antagonists. Pain 49: 121-128, 2011.

107. Zhang S., Ehlers M.D., Bernhardt J.P., Su C.-T., Hzganir R.L. Calmodulin mediates calcium-dependent inactivation of N-methyl-D-aspartate receptors. Neuron 21: 443-453, 1998. 